University of Nebraska - Lincoln

DigitalCommons@University of Nebraska - Lincoln

Publications, Agencies and Staff of the U.S.

Department of Commerce

U.S. Department of Commerce

2007

\title{
Use of chemical tracers in assessing the diet and foraging regions of eastern North Pacific killer whales
}

\author{
Margaret M. Krahn \\ NOAA Fisheries, Northwest Fisheries Science Center \\ David P. Herman \\ NOAA Fisheries, Northwest Fisheries Science Center \\ Craig O. Matkin \\ North Gulf Oceanic Society \\ John W. Durban \\ NOAA Fisheries, Alaska Fisheries Science Center \\ Lance Barrett-Lennard \\ Vancouver Aquarium Marine Science Centre, P.O. Box 3232, Vancouver, BC, Canada V6B-3X8 \\ See next page for additional authors
}

Follow this and additional works at: https://digitalcommons.unl.edu/usdeptcommercepub

Part of the Environmental Sciences Commons

Krahn, Margaret M.; Herman, David P.; Matkin, Craig O.; Durban, John W.; Barrett-Lennard, Lance; Burrows, Douglas G.; Dahlheim, Marilyn E.; Black, Nancy; LeDuc, Richard G.; and Wade, Paul R., "Use of chemical tracers in assessing the diet and foraging regions of eastern North Pacific killer whales" (2007). Publications, Agencies and Staff of the U.S. Department of Commerce. 177.

https://digitalcommons.unl.edu/usdeptcommercepub/177

This Article is brought to you for free and open access by the U.S. Department of Commerce at DigitalCommons@University of Nebraska - Lincoln. It has been accepted for inclusion in Publications, Agencies and Staff of the U.S. Department of Commerce by an authorized administrator of DigitalCommons@University of Nebraska - Lincoln. 


\section{Authors}

Margaret M. Krahn, David P. Herman, Craig O. Matkin, John W. Durban, Lance Barrett-Lennard, Douglas G.

Burrows, Marilyn E. Dahlheim, Nancy Black, Richard G. LeDuc, and Paul R. Wade 


\title{
Use of chemical tracers in assessing the diet and foraging regions of eastern North Pacific killer whales
}

\author{
Margaret M. Krahn ${ }^{\text {a,* }}$, David P. Herman ${ }^{\text {a }}$, Craig O. Matkin b, \\ John W. Durban ${ }^{\text {c }}$, Lance Barrett-Lennard ${ }^{\mathrm{d}}$, Douglas G. Burrows ${ }^{\mathrm{a}}$, \\ Marilyn E. Dahlheim ' ${ }^{\text {, Nancy Black }}{ }^{\mathrm{e}}$, \\ Richard G. LeDuc ${ }^{\text {, }}$, Paul R. Wade ${ }^{\mathrm{c}}$ \\ a NOAA Fisheries, Northwest Fisheries Science Center, 2725 Montlake Boulevard East, Seattle, WA 98112, USA \\ b North Gulf Oceanic Society, 3430 Main Street B1, Homer, AK 99603, USA \\ c NOAA Fisheries, Alaska Fisheries Science Center, 7600 Sand Point Way NE, Seattle, WA 98115, USA \\ d Vancouver Aquarium Marine Science Centre, P.O. Box 3232, Vancouver, BC, Canada V6B-3X8 \\ e Monterey Bay Cetacean Project, P.O. Box 52001, Pacific Grove, CA 93950, USA \\ ${ }^{\mathrm{f}}$ NOAA Fisheries, Southwest Fisheries Science Center, 8604 La Jolla Shores Drive, San Diego, CA 92037, USA
}

Received 8 December 2005; received in revised form 7 July 2006; accepted 10 July 2006

\begin{abstract}
Top predators in the marine environment integrate chemical signals acquired from their prey that reflect both the species consumed and the regions from which the prey were taken. These chemical tracers - stable isotope ratios of carbon and nitrogen; persistent organic pollutant (POP) concentrations, patterns and ratios; and fatty acid profiles - were measured in blubber biopsy samples from North Pacific killer whales (Orcinus orca) $(n=84)$ and were used to provide further insight into their diet, particularly for the offshore group, about which little dietary information is available. The offshore killer whales were shown to consume prey species that were distinctly different from those of sympatric resident and transient killer whales. In addition, it was confirmed that the offshores forage as far south as California. Thus, these results provide evidence that the offshores belong to a third killer whale ecotype. Resident killer whale populations showed a gradient in stable isotope profiles from west (central Aleutians) to east (Gulf of Alaska) that, in part, can be attributed to a shift from off-shelf to continental shelf-based prey. Finally, stable isotope ratio results, supported by field
\end{abstract}

\footnotetext{
* Corresponding author. Tel.: +1 206860 3326; fax: +1 2068603335.

E-mail address: peggy.krahn@noaa.gov (M.M. Krahn).
} 
observations, showed that the diet in spring and summer of eastern Aleutian Island transient killer whales is apparently not composed exclusively of Steller sea lions.

Published by Elsevier Ltd.

Keywords: Feeding ecology; Predation; Biopsy sampling; Chemical pollution; Stable isotopes; Fatty acids; Organochlorines; Brominated diphenyl ethers; Orcinus orca

\section{Introduction}

Assessing the diets and trophic positions of top level marine predators, such as the killer whale (Orcinus orca), is essential in understanding marine food webs. Predation by killer whales has recently been hypothesized to play a role in the population declines of several marine mammal species in Alaskan waters (Estes et al., 1998; National Research Council, 2003; Springer et al., 2003). In the North Pacific, two distinct types of killer whales have been termed "residents" and "transients" (Bigg, 1982; Ford et al., 2000). Whales of these types differ in their genetics (Hoelzel et al., 1998), acoustics (Barrett-Lennard et al., 1996), morphology (Ford et al., 2000) and feeding ecology (Ford et al., 1998). Transients are thought to prey solely on marine mammals and residents are believed to principally consume marine fish, in particular salmon. Thus, transient killer whales are members of a "mammal-eating" ecotype, whereas residents belong to a "fish-eating" ecotype (Baird and Dill, 1995; Ford et al., 1998; Saulitis et al., 2000). A third group, the "offshores," has also been proposed (Ford et al., 2000) to describe whales most commonly encountered in outer coastal waters between California and Alaska (Dahlheim, unpublished data; Ellis, 2005; Krahn et al., 2004a). Offshore killer whales have a different mitochondrial DNA (mtDNA) haplotype from those of resident and transient whales (Barrett-Lennard, 2000; Hoelzel et al., 2002). Although few feeding observations have been reported for the offshores, initial field observations suggest that their diet includes marine fish and perhaps squid (Black, unpublished data; Dahlheim, unpublished data; Ford et al., 2000; Jones, 2006). In order to evaluate whether any of the killer whale populations have played a role in the marine mammal population declines in Alaska, dietary information for all of the Alaska killer whale groups is needed.

Traditional diet analyses have known biases and limitations when applied to marine predators. For example, in Alaska, the "field season" generally extends from late spring to early fall, so information is limited about feeding habits of killer whales at other times of the year. Stomach content analyses provide data only from relatively recent meals and these analyses are typically biased as a result of differential rates of digestion of hard parts (Tollit et al., 1997; Yonezaki et al., 2003). Finally, stomach contents are available only from a small number of stranded animals and these whales may not reflect the eating habits of healthy whales. Thus, to provide data that may better reflect the long-term diets of killer whales, chemical analyses - using biopsy samples from presumably healthy animals - have been developed to further elucidate the dietary specializations of the three types of killer whales.

Mammalian predators, such as killer whales, integrate chemical tracers acquired from their prey that reflect both the species consumed and the regions from which the prey were taken. For example, two chemical signals - fatty acid signature analysis of blubber (Iverson et al., 2004) and stable isotope enrichments of ${ }^{13} \mathrm{C}$ and ${ }^{15} \mathrm{~N}$ in the epidermis (Kelly, 2000)- 
have been used to assess the diet and trophic position of marine mammals. In addition, patterns of persistent organic pollutants (POPs) have been shown to differentiate cetacean stocks (Krahn et al., 1999; Muir et al., 1996), presumably due to differences in POPs in their prey. All three techniques were combined by Herman et al. (2005) to qualitatively examine the dietary specializations of eastern North Pacific killer whale populations.

An additional approach-POP ratios - can be used to assess regional sources of POPs transferred to predators from their prey (Calambokidis and Barlow, 1991; Krahn et al., 1999; Muir et al., 1990). For example, DDTs were used heavily in California before their ban in the 1970s and California marine waters also received long-term, significant discharges of DDTs from a manufacturing plant (Eganhouse et al., 2000). As a result, concentrations of $\sum D D T$ s relative to $\sum$ PCBs (i.e., $\sum D D T s / \sum P C B s$ ratio) are typically higher in California marine species than in comparable species from other eastern North Pacific locations - providing a "California signature" (Brown et al., 1998; Calambokidis and Barlow, 1991; Jarman et al., 1996). Another characteristic contaminant signaturethe "Alaska signature" - has resulted from the continued use in Asia of pesticides, such as $p, p^{\prime}$-DDT and technical hexachlorocyclohexane $(\mathrm{HCH})$, long after their ban in much of the rest of the world (de Wit et al., 2004). Due to transport of contaminants from Asia eastward via air and ocean currents, as well as the eastward migration of pollutant-containing anadromous fish from Asia to the Aleutian Islands and Bering Sea, pollutants used in Asia are often found in marine biota from Alaska (de Wit et al., 2004). For example, the ratio of $p, p^{\prime}$-DDT to $\sum$ DDTs is comparatively high in Alaskan species (de Wit et al., 2004), whereas this ratio is lower in California marine biota, indicating an "old" metabolized source (Aguilar, 1984). Finally, the flame-retardant polybrominated diphenyl ethers (PBDEs), found in urban runoff and sewage effluents, have emerged as an important class of toxicants because of their recent exponential increase in the environment (de Wit, 2002). Thus, investigation of the ratio of $\sum$ PBDEs relative to $\sum$ PCBs can identify sources of contamination indicative of an urban environment.

The current study was undertaken to advance the findings of the previous study (Herman et al., 2005) by providing further insight into diet and movements of the North Pacific killer whales from Alaska. Additional biopsy samples $(n=84)$ were collected from resident, transient and offshore killer whales and were characterized by comparing POP concentrations, patterns and ratios, stable isotope ratios of carbon and nitrogen and fatty acid profiles by killer whale ecotype and region. Interpretation of the results from the additional samples has further demonstrated the differences among the three killer whale groups in feeding habits and movements. For example, the increased sample size for the resident killer whales revealed a gradient in chemical profiles from west (central Aleutians) to east (Gulf of Alaska), consistent with regional differences in their prey. In addition, offshore killer whales were shown to consume a diet that is clearly distinct from those of sympatric residents and transients. Thus, the current study increases the knowledge about the role of killer whales in the marine food web.

\section{Materials and methods}

\subsection{Killer whales sampled}

For this study, killer whale biopsy samples $(n=84)$ were collected in Alaska during the 2003/2004 sampling years. All samples were obtained from live, presumably healthy 
whales using remote biopsy sampling techniques (Barrett-Lennard, 2000; Hoelzel et al., 1998; Ylitalo et al., 2001) and biopsy tips of various lengths (typically 3.0-3.5 cm). All biopsy samples were stored at $-80^{\circ} \mathrm{C}$ until analyzed. Sample sizes were standardized as reported previously (Herman et al., 2005). The blubber acquired from these whales was analyzed for fatty acids and POPs and the epidermis, when available, for stable isotope ratios (Table 1). In several instances, an insufficient quantity of epidermis was available to allow stable isotope analyses to be performed, resulting in data omissions for many samples.

In addition to the samples in Table 1, biopsy samples were analyzed from eastern Tropical Pacific (ETP) male killer whales from waters to the west of Nicaragua $(n=3$; animal IDs: 38168, 38170 and 38175; provided by the Southwest Fisheries Science Center) and from four "West Coast" (California) male transients (animal IDs: 6/02/00, CA-11, CA30 and NB040423-1) provided by the Monterey Bay Cetacean Project. Selected POP results from both the ETP whales and the West Coast transients were used for comparison with those from the Alaskan killer whales.

\subsection{Killer whale group structure}

Each killer whale in this study was provisionally classified as resident, transient or offshore based on field observations and in some cases, on long-term studies of well-known populations. These classifications were corroborated by mtDNA haplotype identity (Barrett-Lennard, 2000). The resident and transient killer whales from Alaska were grouped by geographical collection region in this study and include the Central Aleutian Islands (CAI), Eastern Aleutian Islands (EAI) and Gulf of Alaska (GOA) (Table 1 and Fig. 1). The offshore killer whales were combined into a single group. Although offshores have been encountered as far south as Los Angeles (Black et al., 1997; Ford et al., 2000), mostly in the winter months, only recently have photo-identification resightings of offshore individuals been recorded between Alaska, Washington State and California, thus suggesting a single population with the same individuals moving throughout the northeast Pacific (Dahlheim, unpublished data).

\subsection{Fatty acid analyses}

Fatty acid concentrations in blubber were determined as reported by Krahn et al. (2004b).

\subsection{Persistent organic pollutant analyses}

Blubber from killer whale biopsies was analyzed for POP concentrations using the procedure of Sloan et al. (2004). $\sum$ PCBs is the sum of all 40 PCB congeners analyzed; $\sum \mathrm{DDT}$ is the sum of $o, p^{\prime}$-DDD, $p, p^{\prime}$-DDD, $p, p^{\prime}$-DDE, $o, p^{\prime}$-DDE, $o, p^{\prime}$-DDT and $p, p^{\prime}$-DDT; $\sum$ chlordanes is the sum of oxychlordane, $\gamma$-chlordane, nona-III-chlordane, $\alpha$-chlordane, trans-nonachlor, and cis-nonachlor; the $\sum \mathrm{HCH}$ is the sum of $\alpha-, \beta-$, and $\gamma-\mathrm{HCH}$ isomers and finally $\sum$ PBDEs is the sum of congeners $28,47,49,66,85,99$, $100,153,154,183$. Total lipids in killer whale biopsy samples were measured by a TLC-FID method (Ylitalo et al., 2005c). All POP concentrations reported in this paper have been lipid-normalized. 
Table 1

Collection date, age class, ecotype and location for killer whale biopsy samples analyzed for fatty acids (FA), stable isotopes (SI) and persistent organic contaminants (POPs)

\begin{tabular}{|c|c|c|c|c|c|c|c|c|}
\hline Sample\# & FA & SI & POPs ${ }^{\mathrm{a}}$. & $\begin{array}{l}\text { Animal } \\
\text { dentification }\end{array}$ & $\begin{array}{l}\text { Collection } \\
\text { date }\end{array}$ & Age class & Ecotype & Location \\
\hline \multicolumn{9}{|c|}{ Alaska Offshores (AK/OFF) } \\
\hline 1 & $\mathrm{x}$ & & $\mathrm{x}$ & EA-03-08 & $7 / 10 / 2003$ & Adult & Offshore & $\begin{array}{l}\text { Eastern Aleutian } \\
\text { Islands }\end{array}$ \\
\hline 2 & $\mathrm{x}$ & $\mathrm{x}$ & $\mathrm{x}$ & AKW-04-006 & $7 / 8 / 2004$ & Adult & Offshore & Kenai Fjords \\
\hline 3 & $\mathrm{x}$ & $\mathrm{x}$ & $\mathrm{x}$ & AKW-04-007 & $7 / 8 / 2004$ & Adult & Offshore & Kenai Fjords \\
\hline 4 & $\mathrm{x}$ & $\mathrm{x}$ & $\mathrm{x}$ & 9-16-04 ENC 8 \#2 & $9 / 16 / 2004$ & Adult & Offshore & Southeast Alaska \\
\hline \multicolumn{9}{|l|}{ Females } \\
\hline 5 & $\mathrm{x}$ & & & EA-03-06 & $7 / 10 / 2003$ & Adult & Offshore & $\begin{array}{l}\text { Eastern Aleutian } \\
\text { Islands }\end{array}$ \\
\hline 6 & $\mathrm{x}$ & & & EA-03-07 & $7 / 10 / 2003$ & Adult & Offshore & $\begin{array}{l}\text { Eastern Aleutian } \\
\text { Islands }\end{array}$ \\
\hline 7 & $\mathrm{x}$ & & & EA-03-09 & $7 / 10 / 2003$ & Adult & Offshore & $\begin{array}{l}\text { Eastern Aleutian } \\
\text { Islands }\end{array}$ \\
\hline 8 & $\mathrm{x}$ & $\mathrm{x}$ & & AKW-04-005 & $7 / 8 / 2004$ & Adult & Offshore & Kenai Fjords \\
\hline 9 & $\mathrm{x}$ & $\mathrm{x}$ & & 9-16-04 ENC 8 \#1 & $9 / 16 / 2004$ & Adult & Offshore & Southeast Alaska \\
\hline
\end{tabular}

Central Aleutian Island Residents (CAI/R)

Males

10

11

12

$\begin{array}{llll}\text { X } & \text { X } & \text { X } & \text { CP030710-01 } \\ \text { X } & x & x & \text { CP030710-02 } \\ \text { X } & \text { X } & \text { X } & \text { AE040819-01 }\end{array}$

$\begin{array}{ll}7 / 10 / 2003 & \text { Adult } \\ 7 / 10 / 2003 & \text { Adult } \\ 8 / 19 / 2004 & \text { Adult }\end{array}$

$6 / 29 / 2003$

Unknow

Males

13

X

EA-03-03

14

X $\quad$ X

EA-03-05

15

x $\quad$ x

UNAK-03-001

16

17

18

19

20

21

22

$$
\mathrm{x} \quad \mathrm{x}
$$

UNAK-03-002

UNAK-03-003

EA-03-11

UNAK-03-006

UNAK-03-007

UNAK-03-009

EA-04-001
7/7/2003 Adult

7/7/2003 Adult

7/13/2003 Adult

7/14/2003 Adult

8/1/2003 Adult

8/18/2003 Adult

8/18/2003 Adult

$8 / 22 / 2003$

Sub-adult

$7 / 6 / 2004$

Sub-adult

$\begin{array}{ll}\text { Resident } & \begin{array}{l}\text { Central Aleutian } \\ \text { Islands }\end{array} \\ \text { Resident } & \text { Central Aleutian } \\ & \text { Islands } \\ \text { Resident } & \begin{array}{l}\text { Central Aleutian } \\ \text { Islands }\end{array}\end{array}$

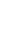


Table 1 (continued)

\begin{tabular}{|c|c|c|c|c|c|c|c|c|}
\hline Sample\# & FA & SI & POPs ${ }^{\mathrm{a}}$. & $\begin{array}{l}\text { Animal } \\
\text { dentification }\end{array}$ & Collection date & Age class & Ecotype & Location \\
\hline 23 & $\mathrm{x}$ & & $\mathrm{x}$ & EA-04-002 & $7 / 8 / 2004$ & Adult & Resident & $\begin{array}{l}\text { Eastern Aleutian } \\
\text { Islands }\end{array}$ \\
\hline 24 & $\mathrm{x}$ & & $\mathrm{x}$ & EA-04-003 & $7 / 10 / 2004$ & Adult & Resident & $\begin{array}{l}\text { Eastern Aleutian } \\
\text { Islands }\end{array}$ \\
\hline 25 & $\mathrm{x}$ & $\mathrm{x}$ & & UNAK-04-001 & $7 / 13 / 2004$ & Unknown & Resident & $\begin{array}{l}\text { Eastern Aleutian } \\
\text { Islands }\end{array}$ \\
\hline 26 & $\mathrm{x}$ & $\mathrm{x}$ & $\mathrm{x}$ & UNAK-04-003 & $7 / 14 / 2004$ & Adult & Resident & $\begin{array}{l}\text { Eastern Aleutian } \\
\text { Islands }\end{array}$ \\
\hline 27 & $\mathrm{x}$ & & $\mathrm{x}$ & UNAK-04-004 & $7 / 23 / 2004$ & Adult & Resident & $\begin{array}{l}\text { Eastern Aleutian } \\
\text { Islands }\end{array}$ \\
\hline 28 & $\mathrm{x}$ & & $\mathrm{x}$ & UNAK-04-005 & $7 / 24 / 2004$ & Adult & Resident & $\begin{array}{l}\text { Eastern Aleutian } \\
\text { Islands }\end{array}$ \\
\hline 29 & $\mathrm{x}$ & $\mathrm{x}$ & $\mathrm{x}$ & AE040728-02 & $7 / 28 / 2004$ & Adult & Resident & $\begin{array}{l}\text { Eastern Aleutian } \\
\text { Islands }\end{array}$ \\
\hline 30 & $\mathrm{x}$ & $\mathrm{x}$ & $\mathrm{x}$ & AE040728-03 & $7 / 28 / 2004$ & Adult & Resident & $\begin{array}{l}\text { Eastern Aleutian } \\
\text { Islands }\end{array}$ \\
\hline 31 & $\mathrm{x}$ & $\mathrm{x}$ & $\mathrm{x}$ & AE040728-04 & $7 / 28 / 2004$ & Adult & Resident & $\begin{array}{l}\text { Eastern Aleutian } \\
\text { Islands }\end{array}$ \\
\hline 32 & $\mathrm{x}$ & $\mathrm{x}$ & $\mathrm{x}$ & AE040728-05 & $7 / 28 / 2004$ & Adult & Resident & $\begin{array}{l}\text { Eastern Aleutian } \\
\text { Islands }\end{array}$ \\
\hline 33 & $\mathrm{x}$ & $\mathrm{x}$ & $\mathrm{x}$ & AE040728-06 & $7 / 28 / 2004$ & Adult & Resident & $\begin{array}{l}\text { Eastern Aleutian } \\
\text { Islands }\end{array}$ \\
\hline 34 & $\mathrm{x}$ & $\mathrm{x}$ & $\mathrm{x}$ & EA-04-004 & $7 / 31 / 2004$ & Adult & Resident & $\begin{array}{l}\text { Eastern Aleutian } \\
\text { Islands }\end{array}$ \\
\hline 35 & $\mathrm{x}$ & $\mathrm{x}$ & $\mathrm{x}$ & EA-04-005 & $8 / 9 / 2004$ & Adult & Resident & $\begin{array}{l}\text { Eastern Aleutian } \\
\text { Islands }\end{array}$ \\
\hline 36 & $\mathrm{x}$ & $\mathrm{x}$ & $\mathrm{x}$ & AE040818-02 & $8 / 18 / 2004$ & Adult & Resident & $\begin{array}{l}\text { Eastern Aleutian } \\
\text { Islands }\end{array}$ \\
\hline \multicolumn{9}{|l|}{ Females } \\
\hline 37 & $\mathrm{x}$ & & & EA-03-04 & $6 / 29 / 2003$ & Adult & Resident & $\begin{array}{l}\text { Eastern Aleutian } \\
\text { Islands }\end{array}$ \\
\hline 38 & $\mathrm{x}$ & $\mathrm{x}$ & & UNAK-04-002 & $7 / 14 / 2004$ & Adult & Resident & $\begin{array}{l}\text { Eastern Aleutian } \\
\text { Islands }\end{array}$ \\
\hline
\end{tabular}

Gulf of Alaska Residents (GOA/R)

Males

39

40

41

42

43
X

X

AKW-03-06

$7 / 21 / 2003$

AKW-03-08

X

X

X

AKW-03-10

AKW-03-14
$8 / 3 / 2003$

$8 / 3 / 2003$

$8 / 4 / 2003$

$9 / 5 / 2003$
Adult Resident Prince William Sound/ Kenai Fjords

Adult Resident Prince William Sound/ Kenai Fjords

Adult Resident Prince William Sound/ Kenai Fjords

Adult Resident Prince William Sound/ Kenai Fjords

Adult Resident Prince William Sound/ Kenai Fjords 
Table 1 (continued)

\begin{tabular}{|c|c|c|c|c|c|c|c|c|}
\hline Sample\# & FA & SI & POPs $^{\mathrm{a}}$. & $\begin{array}{l}\text { Animal } \\
\text { dentification }\end{array}$ & Collection date & Age class & Ecotype & Location \\
\hline 44 & $\mathrm{x}$ & $\mathrm{x}$ & $\mathrm{x}$ & AKW-04-01 & $5 / 22 / 2004$ & Adult & Resident & $\begin{array}{l}\text { Prince William } \\
\text { Sound }\end{array}$ \\
\hline 45 & $\mathrm{x}$ & $\mathrm{x}$ & $\mathrm{x}$ & AKW-04-010 & $8 / 3 / 2004$ & Adult & Resident & Kenai Fjords \\
\hline 46 & $\mathrm{x}$ & & $\mathrm{x}$ & PWS-04-01 & $8 / 4 / 2004$ & Adult & Resident & $\begin{array}{l}\text { Prince William } \\
\text { Sound }\end{array}$ \\
\hline 47 & $\mathrm{x}$ & & & PWS-04-02 & $8 / 4 / 2004$ & Sub-adult & Resident & $\begin{array}{l}\text { Prince William } \\
\text { Sound }\end{array}$ \\
\hline 48 & $\mathrm{x}$ & $\mathrm{x}$ & $\mathrm{x}$ & PWS-04-03 & $8 / 7 / 2004$ & Adult & Resident & $\begin{array}{l}\text { Prince William } \\
\text { Sound }\end{array}$ \\
\hline 49 & $\mathrm{x}$ & $\mathrm{x}$ & $\mathrm{x}$ & PWS-04-04 & $8 / 7 / 2004$ & Adult & Resident & $\begin{array}{l}\text { Prince William } \\
\text { Sound }\end{array}$ \\
\hline 50 & $\mathrm{x}$ & & $\mathrm{x}$ & PWS-04-05 & $8 / 7 / 2004$ & Adult & Resident & $\begin{array}{l}\text { Prince William } \\
\text { Sound }\end{array}$ \\
\hline 51 & $\mathrm{x}$ & & $\mathrm{x}$ & PWS-04-06 & $8 / 10 / 2004$ & Adult & Resident & $\begin{array}{l}\text { Prince William } \\
\text { Sound }\end{array}$ \\
\hline 52 & $\mathrm{x}$ & & $\mathrm{x}$ & AKW-04-012 & $8 / 14 / 2004$ & Adult & Resident & Kenai Fjords \\
\hline 53 & $\mathrm{x}$ & & & AKW-04-013 & $8 / 15 / 2004$ & Sub-adult & Resident & Kenai Fjords \\
\hline 54 & $\mathrm{x}$ & & $\mathrm{x}$ & PWS-04-07 & $9 / 6 / 2004$ & Adult & Resident & $\begin{array}{l}\text { Prince William } \\
\text { Sound }\end{array}$ \\
\hline 55 & $\mathrm{x}$ & & & PWS-04-08 & $9 / 6 / 2004$ & Sub-adult & Resident & $\begin{array}{l}\text { Prince William } \\
\text { Sound }\end{array}$ \\
\hline 56 & $\mathrm{x}$ & & $\mathrm{x}$ & AKW-03-02 & Unknown & Adult & Resident & Kenai Fjords \\
\hline 57 & $\mathrm{x}$ & & $\mathrm{x}$ & AKW-03-03 & Unknown & Adult & Resident & Kenai Fjords \\
\hline 58 & $\mathrm{x}$ & & $\mathrm{x}$ & AKW-03-04 & Unknown & Adult & Resident & $\begin{array}{l}\text { Prince William } \\
\text { Sound/ Kenai } \\
\text { Fjords }\end{array}$ \\
\hline $\begin{array}{l}\text { Females } \\
59\end{array}$ & $\mathrm{x}$ & $\mathrm{x}$ & & AKW-04-02 & $5 / 22 / 2004$ & Adult & Resident & $\begin{array}{l}\text { Prince William } \\
\text { Sound }\end{array}$ \\
\hline 60 & $\mathrm{x}$ & & & AKW-03-01 & Unknown & Adult & Resident & Kenai Fjords \\
\hline
\end{tabular}

Eastern Aleutian Island Transients (EAI/T)

\section{Males}

62

62

63

64

65

66

67

68

69 $\mathrm{x}$

\begin{abstract}
$\mathrm{x}$
\end{abstract}
FP-03-01

$5 / 19 / 2003$

FP-03-03

$5 / 20 / 2003$

FP-03-06

FP-03-07

FP-03-08

FP-04-025

$5 / 30 / 2003$

FP-03-09 5/31/2003

EA-03-10

$7 / 30 / 2003$

FP-04-01

$5 / 4 / 2004$
Adult

Adult

Adult

Adult

Adult

Adult

Adult

Adult

Adult
Transient Eastern Aleutian Islands

Transient Eastern Aleutian Islands

Transient Eastern Aleutian Islands

Transient Eastern Aleutian Islands

Transient Eastern Aleutian Islands

Transient Eastern Aleutian Islands

Transient Eastern Aleutian Islands

Transient Eastern Aleutian Islands

Transient Eastern Aleutian Islands (continued on next page) 
Table 1 (continued)

\begin{tabular}{|c|c|c|c|c|c|c|c|c|}
\hline Sample\# & FA & SI & POPs $^{\mathrm{a}}$. & $\begin{array}{l}\text { Animal } \\
\text { dentification }\end{array}$ & Collection date & Age class & Ecotype & Location \\
\hline 70 & $\mathrm{x}$ & $\mathrm{x}$ & $\mathrm{x}$ & FP-04-02 & $5 / 4 / 2004$ & Adult & Transient & $\begin{array}{l}\text { Eastern Aleutian } \\
\text { Islands }\end{array}$ \\
\hline 62 & $\mathrm{x}$ & $\mathrm{x}$ & $\mathrm{x}$ & FP-04-08 & $5 / 5 / 2004$ & Adult & Transient & $\begin{array}{l}\text { Eastern Aleutian } \\
\text { Islands }\end{array}$ \\
\hline 63 & $\mathrm{x}$ & $\mathrm{x}$ & $\mathrm{x}$ & FP-04-14 & $5 / 8 / 2004$ & Adult & Transient & $\begin{array}{l}\text { Eastern Aleutian } \\
\text { Islands }\end{array}$ \\
\hline 64 & $\mathrm{x}$ & $\mathrm{x}$ & & FP-04-15 & $5 / 9 / 2004$ & Sub-adult & Transient & $\begin{array}{l}\text { Eastern Aleutian } \\
\text { Islands }\end{array}$ \\
\hline 65 & $\mathrm{x}$ & & & UNAK-04-06 & $7 / 30 / 2004$ & Sub-adult & Transient & $\begin{array}{l}\text { Eastern Aleutian } \\
\text { Islands }\end{array}$ \\
\hline 66 & $\mathrm{x}$ & $\mathrm{x}$ & $\mathrm{x}$ & AE040804-01 & $8 / 4 / 2004$ & Adult & Transient & $\begin{array}{l}\text { Eastern Aleutian } \\
\text { Islands }\end{array}$ \\
\hline 67 & $\mathrm{x}$ & $\mathrm{x}$ & $\mathrm{x}$ & AE040815-01 & $8 / 15 / 2004$ & Adult & Transient & $\begin{array}{l}\text { Eastern Aleutian } \\
\text { Islands }\end{array}$ \\
\hline 68 & $\mathrm{x}$ & $\mathrm{x}$ & $\mathrm{x}$ & AE040817-01 & $8 / 17 / 2004$ & Adult & Transient & $\begin{array}{l}\text { Eastern Aleutian } \\
\text { Islands }\end{array}$ \\
\hline \multicolumn{9}{|l|}{ Females } \\
\hline 69 & $\mathrm{x}$ & & & FP-03-05 & $5 / 22 / 2003$ & Adult & Transient & $\begin{array}{l}\text { Eastern Aleutian } \\
\text { Islands }\end{array}$ \\
\hline 70 & $\mathrm{x}$ & $\mathrm{x}$ & & FP-04-03 & $5 / 4 / 2004$ & Adult & Transient & $\begin{array}{l}\text { Eastern Aleutian } \\
\text { Islands }\end{array}$ \\
\hline 71 & $\mathrm{x}$ & & & FP-04-04 & $5 / 4 / 2004$ & Adult & Transient & $\begin{array}{l}\text { Eastern Aleutian } \\
\text { Islands }\end{array}$ \\
\hline 72 & $\mathrm{x}$ & $\mathrm{x}$ & & FP-04-05 & $5 / 4 / 2004$ & Adult & Transient & $\begin{array}{l}\text { Eastern Aleutian } \\
\text { Islands }\end{array}$ \\
\hline 73 & $\mathrm{x}$ & $\mathrm{x}$ & & FP-04-06 & $5 / 5 / 2004$ & Adult & Transient & $\begin{array}{l}\text { Eastern Aleutian } \\
\text { Islands }\end{array}$ \\
\hline 74 & $\mathrm{x}$ & $\mathrm{x}$ & & FP-04-09 & $5 / 5 / 2004$ & Adult & Transient & $\begin{array}{l}\text { Eastern Aleutian } \\
\text { Islands }\end{array}$ \\
\hline 75 & $\mathrm{x}$ & $\mathrm{x}$ & & FP-04-11 & $5 / 7 / 2004$ & Adult & Transient & $\begin{array}{l}\text { Eastern Aleutian } \\
\text { Islands }\end{array}$ \\
\hline 76 & $\mathrm{x}$ & $\mathrm{x}$ & & FP-04-12 & $5 / 7 / 2004$ & Adult & Transient & $\begin{array}{l}\text { Eastern Aleutian } \\
\text { Islands }\end{array}$ \\
\hline 77 & $\mathrm{x}$ & $\mathrm{x}$ & & FP-04-16 & $5 / 13 / 2004$ & Adult & Transient & $\begin{array}{l}\text { Eastern Aleutian } \\
\text { Islands }\end{array}$ \\
\hline 78 & $\mathrm{x}$ & $\mathrm{x}$ & & FP-04-17 & $5 / 13 / 2004$ & Adult & Transient & $\begin{array}{l}\text { Eastern Aleutian } \\
\text { Islands }\end{array}$ \\
\hline 79 & $\mathrm{x}$ & & & FP-04-018 & $5 / 19 / 2004$ & Adult & Transient & $\begin{array}{l}\text { Eastern Aleutian } \\
\text { Islands }\end{array}$ \\
\hline 80 & $\mathrm{x}$ & & & FP-04-021 & $5 / 20 / 2004$ & Adult & Transient & $\begin{array}{l}\text { Eastern Aleutian } \\
\text { Islands }\end{array}$ \\
\hline 81 & $\mathrm{x}$ & $\mathrm{x}$ & & FP-04-022 & $5 / 21 / 2004$ & Adult & Transient & $\begin{array}{l}\text { Eastern Aleutian } \\
\text { Islands }\end{array}$ \\
\hline 82 & $\mathrm{x}$ & $\mathrm{x}$ & & FP-04-023 & $5 / 26 / 2004$ & Adult & Transient & $\begin{array}{l}\text { Eastern Aleutian } \\
\text { Islands }\end{array}$ \\
\hline 83 & $\mathrm{x}$ & $\mathrm{x}$ & & FP-04-024 & $5 / 26 / 2004$ & Sub-adult & Transient & $\begin{array}{l}\text { Eastern Aleutian } \\
\text { Islands }\end{array}$ \\
\hline 84 & $\mathrm{x}$ & $\mathrm{x}$ & & AE040807-01 & $8 / 7 / 2004$ & Adult & Transient & $\begin{array}{l}\text { North Alaska } \\
\text { Pennisula }\end{array}$ \\
\hline
\end{tabular}

a Although POP analyses were conducted for all killer whales in this table, only adult males " $\mathrm{x}$ " were used for POP concentrations (Table 3) and ratios (Figs. 3-6) 


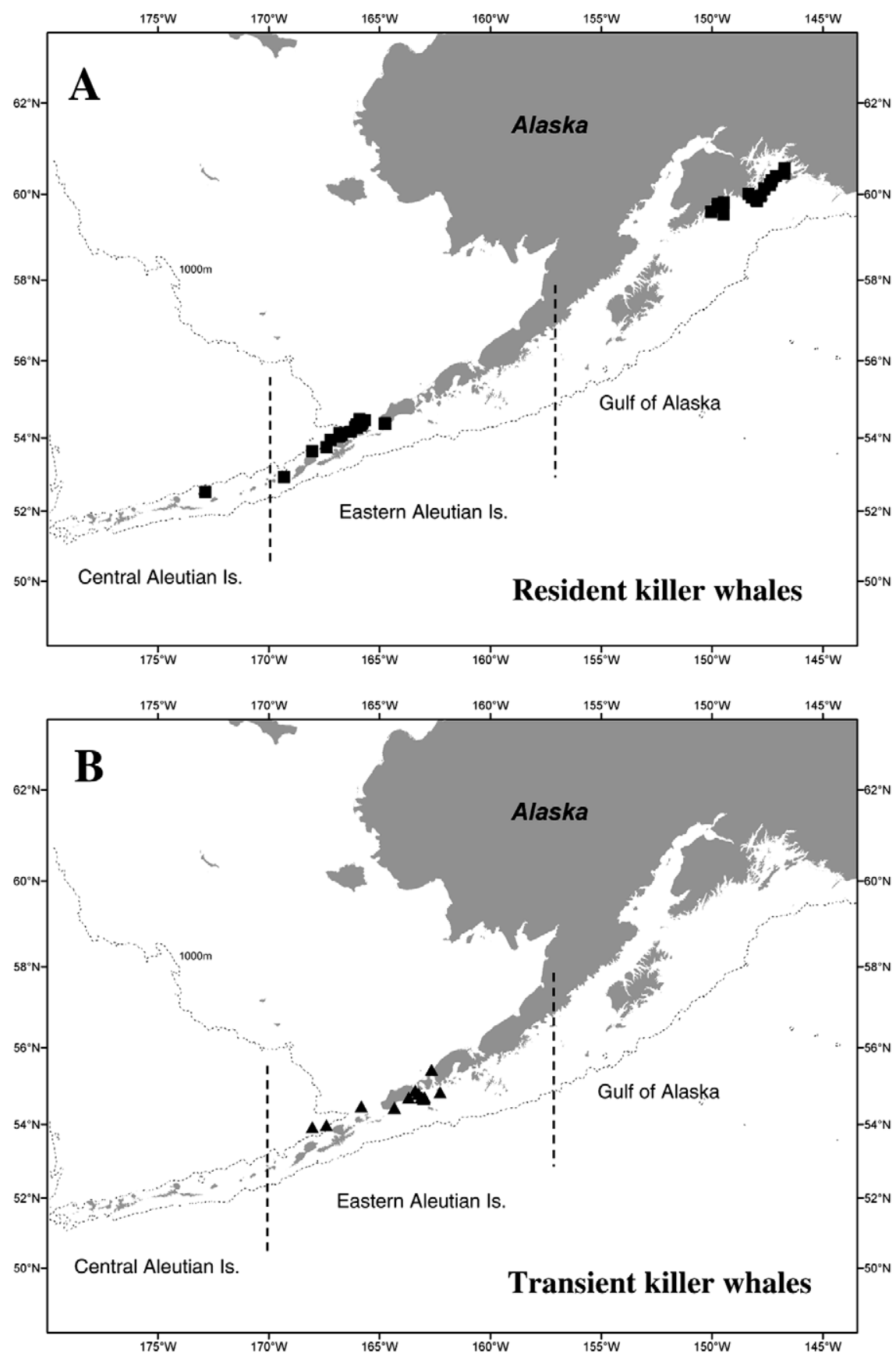

Fig. 1. Map showing location of killer whales that were biopsied in Alaskan waters: (A) resident killer whales and (B) transient killer whales from three regions - the Central Aleutian Islands (CAI); the Eastern Aleutian Islands (EAI); and the Gulf of Alaska (GOA). When a number of animals were encountered at a single location, the plot shows one symbol. The light gray dotted line depicts the approximate location of the continental shelf in these areas. 
POP concentrations in selected putative prey species of killer whales were obtained from a number of sources: whole bodies of California Chinook salmon (O'Neill et al., 2005; Ylitalo et al., 2005a); blubber of gray whales (Krahn et al., 2001); blubber of California sea lions (necropsy) (Ylitalo et al., 2005b); whole bodies of Cook Inlet Chinook (NMFS, unpublished data); and blubber of Steller sea lion pups (biopsy) from Prince William Sound (NMFS, unpublished data), harbor seals from the Aleutian Islands and near Homer, Alaska (NMFS, unpublished data) and northern fur seals (necropsy) from the Pribilof Islands (NMFS, unpublished data).

\subsection{Quality assurance (POPs and fatty acids)}

As part of a performance-based quality assurance program, quality control samples [i.e., method blank, replicate and standard reference materials (SRMs)] were analyzed with each set of field samples (POP and fatty acid samples). Results obtained were in excellent agreement with certified and reference values published by National Institute of Standards and Technology for each SRM material; other quality control samples met established laboratory criteria.

\subsection{Analyses for stable isotope ratios of carbon and nitrogen}

Stable isotope analyses of epidermis from killer (Alaska), gray (Russia and Alaska) and minke (Aleutian Islands) whales, as well as muscle from northern fur seals (Pribilof Islands) and Steller sea lions (Alaska), were conducted on lipid-extracted tissues as described previously (Herman et al., 2005). The internal laboratory standards were calibrated relative to the following international standards: USGS-24 graphite, NBS-22 oil, IAEA-CH-6 sucrose, IAEA-N-1 ammonium sulfate and IAEA-N-2 ammonium sulfate. A standard reference material (NIST SRM 1946) was processed with every 20 analyses to monitor analytical accuracy.

\subsection{Stable isotope ratio modeling}

Stable isotope modeling was conducted using equations and methods reported previously (Herman et al., 2005).

\subsection{Statistical analyses}

All univariate and multivariate analyses were conducted using JMP Statistical Discovery Software (PC profession edition, version 5.01). Prior to all statistical calculations, both untransformed and log-transformed stable isotope and POP concentration data for each regional killer whale group were tested for data normality. The log-transformed data did not lead to a consistent improvement in data normality compared to the untransformed results. Hence, all statistical comparison tests used to evaluate the statistical significance of differences among the various groups were computed from the raw, untransformed data. Unless indicated otherwise, all univariate comparisons between two group means were significance tested $(\alpha=0.05)$ using a two sample Student's $t$-test assuming unequal variances. Significant differences among multiple groups having equal variances were evaluated using a Tukey HSD test $(\alpha=0.05)$. 


\section{Results}

\subsection{Killer whale photoidentification}

Of the nine offshore killer whales biopsied in Alaska [this study and Herman et al. (2005)], three have been sighted in California and four others that were sampled in the Aleutian Islands have been sighted in SE Alaska, but have not been seen in California. Only two of the Alaska offshore whales have not been matched to another region.

\subsection{Stable isotope ratios and modeling}

The killer whales in this study with sufficient epidermis for stable isotope analysis are indicated in Table 1 and the results are given in Fig. 2 and Table 2. In general, the carbon and nitrogen values (Table 2) were not statistically significantly different from those reported previously by Herman et al. (2005). Among killer whale groups shown in Fig. 2, the mean $\delta^{15} \mathrm{~N}$ and $\delta^{13} \mathrm{C}$ values for the transients were significantly higher than the means for the residents, whereas the offshores had intermediate values and were not significantly different from the other two groups. For the three regional groups of Alaska residents (Fig. 2), a significant increase in mean $\delta^{13} \mathrm{C}$ values was noted from west

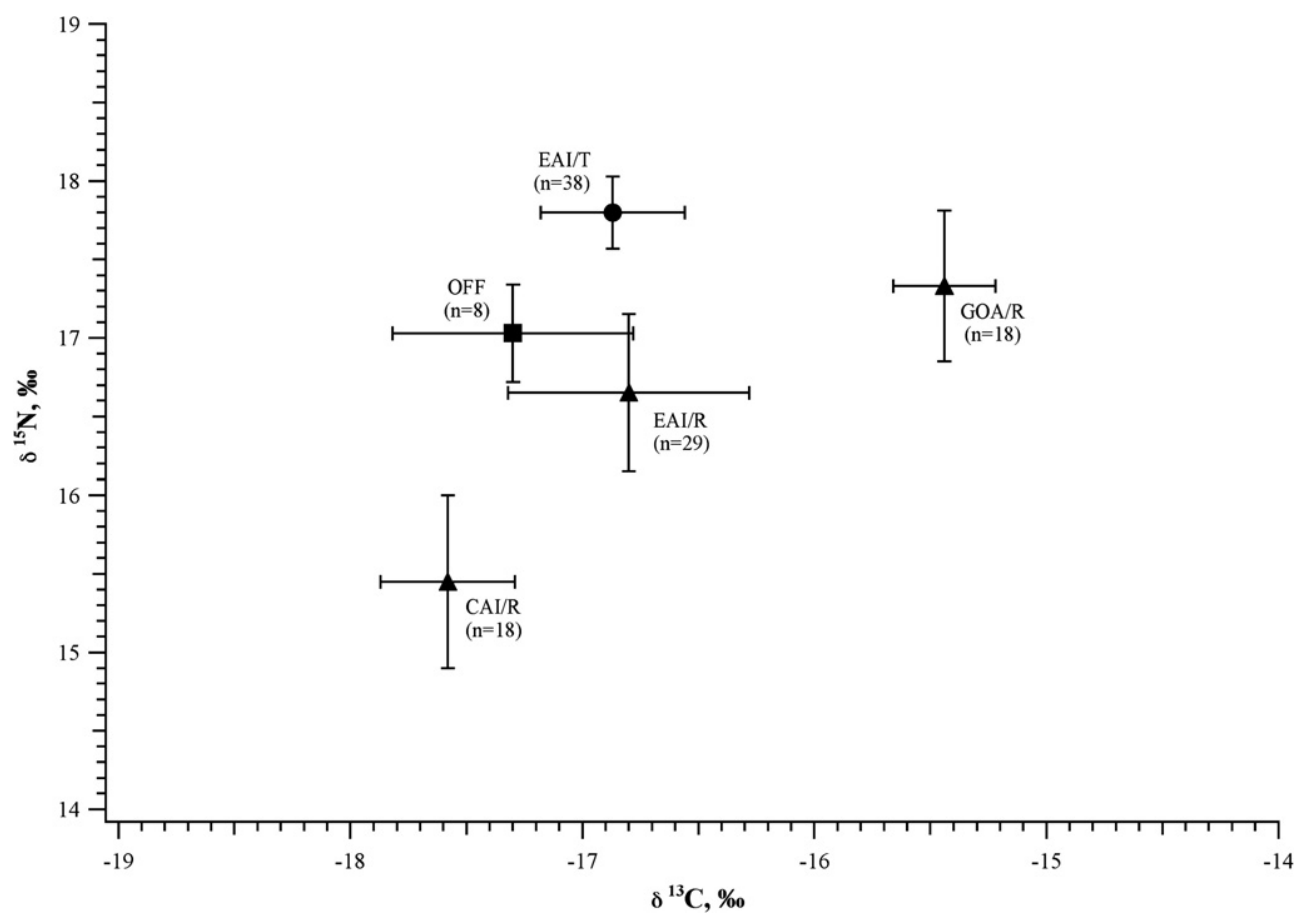

Fig. 2. Nitrogen and carbon stable isotope ratios for killer whale ecotypes (T, transients; R, residents and OFF, offshores). Other abbreviations are identical to those reported in Fig. 1. Killer whales, both from Table 1 and Herman et al. (2005), are included. 
Table 2

Mean ( $\pm 1 \mathrm{SD})$ stable isotope values for killer whales ${ }^{\mathrm{a}}$ from Alaska by region and ecotype, as well as prey species of transient killer whales

\begin{tabular}{llrll}
\hline & Group & $n$ & $\delta^{13} \mathrm{C}$ & $\delta^{15} \mathrm{~N}$ \\
\hline Killer whales & & & & \\
Offshores & AK/OFF & 5 & $-16.5 \pm 0.3$ & $17.0 \pm 0.1$ \\
Residents & CAI/R & 3 & $-18.2 \pm 0.5$ & $14.0 \pm 0.5$ \\
& EAI/R & 13 & $-17.0 \pm 1.9$ & $16.4 \pm 1.7$ \\
& GOA/R & 6 & $-15.4 \pm 0.4$ & $17.6 \pm 0.5$ \\
Mean(residents) $\pm \mathrm{SD}$ & $\mathrm{EAI} / \mathrm{T}$ & 22 & $-17.2 \pm 1.0$ & $17.8 \pm 0.8$ \\
Transients & & $-17.2 \pm 1.0$ & $17.8 \pm 0.8$ \\
Prey species of transients & & & \\
gray whale & & $-16.6 \pm 0.7$ & $13.2 \pm 0.8$ \\
northern fur seal & & $-19.5 \pm 0.8$ & $16.7 \pm 0.5$ \\
minke whale & & -19.2 & 12.4 \\
steller sea lion & 1 & $-17.5 \pm 0.5$ & $16.3 \pm 1.2$ \\
\hline
\end{tabular}

R, resident; T, transient; OFF, offshore; AK, Alaska; EAI, Eastern Aleutian Islands; CAI, Central Aleutian Islands; GOA, Gulf of Alaska.

${ }^{\mathrm{a}}$ Whales from Table 1.

to east $(\mathrm{CAI} / \mathrm{R}<\mathrm{EAI} / \mathrm{R}<\mathrm{GOA} / \mathrm{R})$. The mean $\delta^{15} \mathrm{~N}$ values for the resident groups showed the same trend, but only $\mathrm{CAI} / \mathrm{R}$ was statistically different from $\mathrm{GOA} / \mathrm{R}$ and $\mathrm{EAI} / \mathrm{R}$.

Calculated stable isotope values for the diet of EAI/T killer whales were estimated using Eqs. 2 and 3 from Herman et al. (2005) and were based on observed predation events and stable isotope values measured for the observed prey species from archived marine mammal prey tissues (epidermis or muscle). EAI/T whales were observed to be preying exclusively on juvenile gray whales in May, but later in the summer their observed diet was estimated to comprise northern fur seals $(58 \%)$ minke whales $(28 \%)$ and Steller sea lions $(14 \%)$ (Matkin and Saulitis, unpublished data). Using the stable isotope values of these four prey species (Table 2) and assuming equal weights for these two observed seasonal diets, the predicted carbon and nitrogen isotope values $\left(\delta_{\text {model-C }}=-16.6 \pm 0.4\right.$; $\left.\delta_{\text {model-N }}=18.1 \pm 0.4\right)$ were similar to those actually measured for EAI/T whales $\left(\delta^{13} \mathrm{C}=-17.2 \pm 10, \delta^{15} \mathrm{~N}=17.8 \pm 0.8\right)$.

\subsection{Fatty acid profiles}

For resident, transient and offshore killer whales, the mean summed fatty acid methyl ester weight percent values in each class of blubber fatty acids were similar to those reported previously by Herman et al. (2005), so fatty acid summary data from these additional 84 killer whale biopsy samples are not reported again here. However, because of the increased statistical certainty obtained as a result of the substantial increase in the number of biopsy samples analyzed in the current study, a longitudinal variation was observed for the first time in the fatty acid results for the three regional Alaska resident groups, in which the proportion of $\omega-3$ and polyunsaturated fatty acids was observed to increase $(p<0.05)$ from west to east $(\mathrm{CAI} / \mathrm{R}<\mathrm{EAI} / \mathrm{R}<\mathrm{GOA} / \mathrm{R})$. 


\subsection{POP concentrations}

Only adult male killer whales were used to study differences in POP concentrations, because reproductive female killer whales transfer a substantial portion of their contaminant burden to their calves. As a result, POP concentrations in females are generally lower than in males and are dependent of the number of times they have given birth (Borga et al., 2004; Ross et al., 2000; Ylitalo et al., 2001). Mean concentrations for $\sum$ PCBs, $\sum D D T s$, $\sum$ chlordanes, $\sum$ HCHs and $\sum$ PBDEs measured in the biopsy blubber of adult male offshores from Alaska, transients from the eastern Aleutian Island and residents from three regions (CAI, EAI and GOA) are shown in Table 3. Two other groups of killer whalesthe West Coast transients from California (Table 3) and the ETP whales from waters near Nicaragua (Krahn et al., 2006) — were used for comparison with the whales from Alaska. Contaminant concentrations in male killer whales generally increase with age (Ross et al., 2000), so these concentrations typically have large ranges.

For the killer whales in Table 3, the West Coast (California) transients had significantly higher $\sum$ PCBs, $\sum D D T$ s and $\sum$ PBDEs, whereas the EAI/T whales had significantly higher $\sum \mathrm{HCHs}$, compared to the other whale groups. Among the Alaska killer whales, $\sum$ DDT concentrations in the offshores were two times higher than those of the Alaska transients and 20 times higher than those of the residents (all values significantly different; Table 3). Furthermore, $\sum$ PCB concentrations of offshores were similar to those of the Alaska transients and both were significantly higher than those of the residents. In contrast, $\sum$ chlordanes and $\sum \mathrm{HCH}$ were significantly higher in the Alaska transients than in either the offshores or residents. Finally, mean concentrations of $\sum$ PBDEs (flame retardants) in offshore killer whales were significantly higher than those found for the transients and both were significantly higher than $\sum$ PBDEs for the residents. Comparing the three regional groups of Alaska resident killer whales, mean concentrations for both $\sum$ PCBs and $\sum D D T$ s were about two times higher for the CAI/R and EAI/R whales than for GOA/R residents (Table 3), but only the differences between the EAI/R and GOA/R groups were statistically significant. Mean concentrations of $\sum$ chlordanes were significantly higher for the EAI/R than for the GOA/R population, whereas the differences between the EAI/R and CAI/R groups, as well as the GOA/R and CAI/R groups, were not significant. Both the GOA/R and EAI/R whales had higher mean concentrations of $\sum \mathrm{HCH}$ than were found for $\mathrm{CAI} / \mathrm{R}$ residents but differences were not significant. Finally, the mean concentration of $\sum$ PBDEs was significantly higher in the GOA/R whales compared to the other two regional groups.

\subsection{POP ratios}

Only adult male killer whales were used to study differences in POP ratios, because females can transfer individual POPs at differential rates to their offspring (Borga et al., 2004), resulting in changes in these ratios. In this study, four different contaminant ratios $\sum \mathrm{DDT} / \sum \mathrm{PCBs} ; p, p^{\prime}$-DDT/ $\sum \mathrm{DDT}$; $\sum$ chlordanes/ $\sum \mathrm{PCBs} ; \sum \mathrm{PBDEs} / \sum \mathrm{PCBs}$; Figs. 3-6) were used to evaluate differences among killer whale groups and their prey species and to broadly define regional characteristics of each group. In addition, POP ratio from two other groups of killer whales - the West Coast transients from California and the ETP whales from waters near Nicaragua-were used for comparison with those from the Alaska whales. Ratios for West Coast (California) transients $(n=4)$ are depicted in 
Table 3

Mean $( \pm 1 \mathrm{SD})$ and range of persistent organic pollutants (ng/g lipid) and percent lipid in blubber biopsy samples from adult male offshore, resident and transient killer whales ${ }^{\mathrm{a}}$

\begin{tabular}{|c|c|c|c|c|c|c|c|}
\hline & \multicolumn{4}{|l|}{ Residents (Alaska) } & \multirow{2}{*}{$\begin{array}{l}\text { Offshores } \\
\text { Alaska }(n=4)\end{array}$} & \multicolumn{2}{|l|}{ Transients } \\
\hline & $\begin{array}{l}\text { Central Aleutian } \\
\text { Islands }(n=3)\end{array}$ & $\begin{array}{l}\text { Eastern Aleutian } \\
\text { Islands }(n=20)\end{array}$ & $\begin{array}{l}\text { Gulf of Alaska } \\
(n=17)\end{array}$ & $\begin{array}{l}\text { Mean of all } \\
\text { residents }(n=40)\end{array}$ & & $\begin{array}{l}\text { Eastern Aleutian } \\
\text { Islands (Alaska) }(n=15)\end{array}$ & $\begin{array}{l}\text { West Coast } \\
\text { (California) }(n=4)\end{array}$ \\
\hline$\sum \mathrm{PCBs}$ & $\begin{array}{l}15,000 \pm 1100 \\
(14,000-16,000)\end{array}$ & $\begin{array}{l}16,000 \pm 4900 \\
(9800-28,000)\end{array}$ & $\begin{array}{l}9300 \pm 5200 \\
(1900-18,000)\end{array}$ & $\begin{array}{l}13,000 \pm 5900 \\
(1900-28,000)\end{array}$ & $\begin{array}{l}110,000 \pm 22,000 \\
(81,000-130,000)\end{array}$ & $\begin{array}{l}120,000 \pm 49,000 \\
(59,000-250,000)\end{array}$ & $\begin{array}{l}630,000 \pm 190,000 \\
(350,000-720,000)\end{array}$ \\
\hline$\sum \mathrm{DDTs}$ & $\begin{array}{l}26,000 \pm 1200 \\
(25,000-27,000)\end{array}$ & $\begin{array}{l}27,000 \pm 12,000 \\
(12,000-51,000)\end{array}$ & $\begin{array}{l}13,000 \pm 7800 \\
(1500-28,000)\end{array}$ & $\begin{array}{l}21,000 \pm 12,000 \\
(1500-51,000)\end{array}$ & $\begin{array}{l}420,000 \pm 100,000 \\
(290,000-510,000)\end{array}$ & $\begin{array}{l}200,000 \pm 110,000 \\
(75,000-470,000)\end{array}$ & $\begin{array}{l}3,700,000 \pm 910,000 \\
(2,500,000-4,600,000)\end{array}$ \\
\hline$\sum$ Chlordanes & $\begin{array}{l}4700 \pm 750 \\
(4200-5600)\end{array}$ & $\begin{array}{l}7300 \pm 1500 \\
(4800-11,000)\end{array}$ & $\begin{array}{l}5200 \pm 2900 \\
(930-11,000)\end{array}$ & $\begin{array}{l}6200 \pm 2400 \\
(930-11,000)\end{array}$ & $\begin{array}{l}16,000 \pm 2300 \\
(13,000-18,000)\end{array}$ & $\begin{array}{l}71,000 \pm 24,000 \\
(40,000-120,000)\end{array}$ & $\begin{array}{l}56,000 \pm 12,000 \\
(47,000-74,000)\end{array}$ \\
\hline$\sum \mathrm{HCHs}$ & $\begin{array}{l}280 \pm 29 \\
(250-300)\end{array}$ & $\begin{array}{l}570 \pm 180 \\
(210-900)\end{array}$ & $\begin{array}{l}510 \pm 210 \\
(110-1000)\end{array}$ & $\begin{array}{l}520 \pm 200 \\
(110-1000)\end{array}$ & $\begin{array}{l}500 \pm 87 \\
(440-610)\end{array}$ & $\begin{array}{l}9800 \pm 3400 \\
(4100-16,000)\end{array}$ & $\begin{array}{l}4800 \pm 1100 \\
(3300-7600)\end{array}$ \\
\hline$\sum$ PBDEs & $\begin{array}{l}36 \pm 32 \\
(<\mathrm{LOQ}-57)\end{array}$ & $\begin{array}{l}50 \pm 29 \\
(<\mathrm{LOQ}-110)\end{array}$ & $\begin{array}{l}120 \pm 89 \\
(<\mathrm{LOQ}-270)\end{array}$ & $\begin{array}{l}76 \pm 70 \\
(<\mathrm{LOQ}-270)\end{array}$ & $\begin{array}{l}3,300 \pm 940 \\
(2200-4400)\end{array}$ & $\begin{array}{l}790 \pm 590 \\
(93-2100)\end{array}$ & $\begin{array}{l}12,600 \\
(n=1)\end{array}$ \\
\hline$\%$ Lipid & $23.9 \pm 14.3$ & $23.7 \pm 11.8$ & $27.4 \pm 8.9$ & $25.4 \pm 10.8$ & $17.9 \pm 3.7$ & $21.3 \pm 7.7$ & $13.8 \pm 4.4$ \\
\hline
\end{tabular}

${ }^{\mathrm{a}}$ For mean and standard deviation calculations, $<$ LOQ was set $=0$. 




Fig. 3. The ratios $\sum D D T s / \sum P C B s \pm 1$ SD in adult male killer whale populations and selected putative prey species (matching patterns).

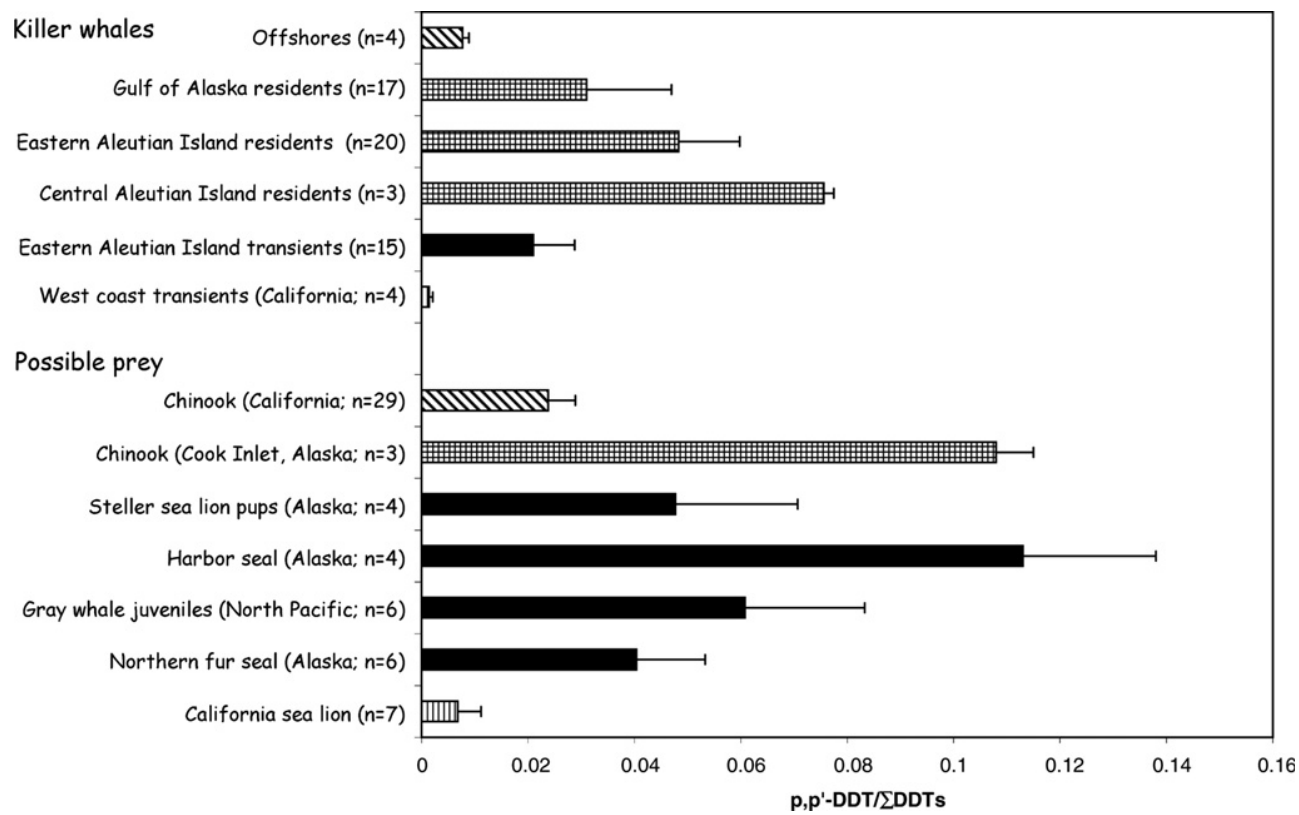

Fig. 4. The ratios $p, p^{\prime}-\mathrm{DDT} / \sum \mathrm{DDTs} \pm 1 \mathrm{SD}$ in adult male killer whale populations and selected putative prey species. 


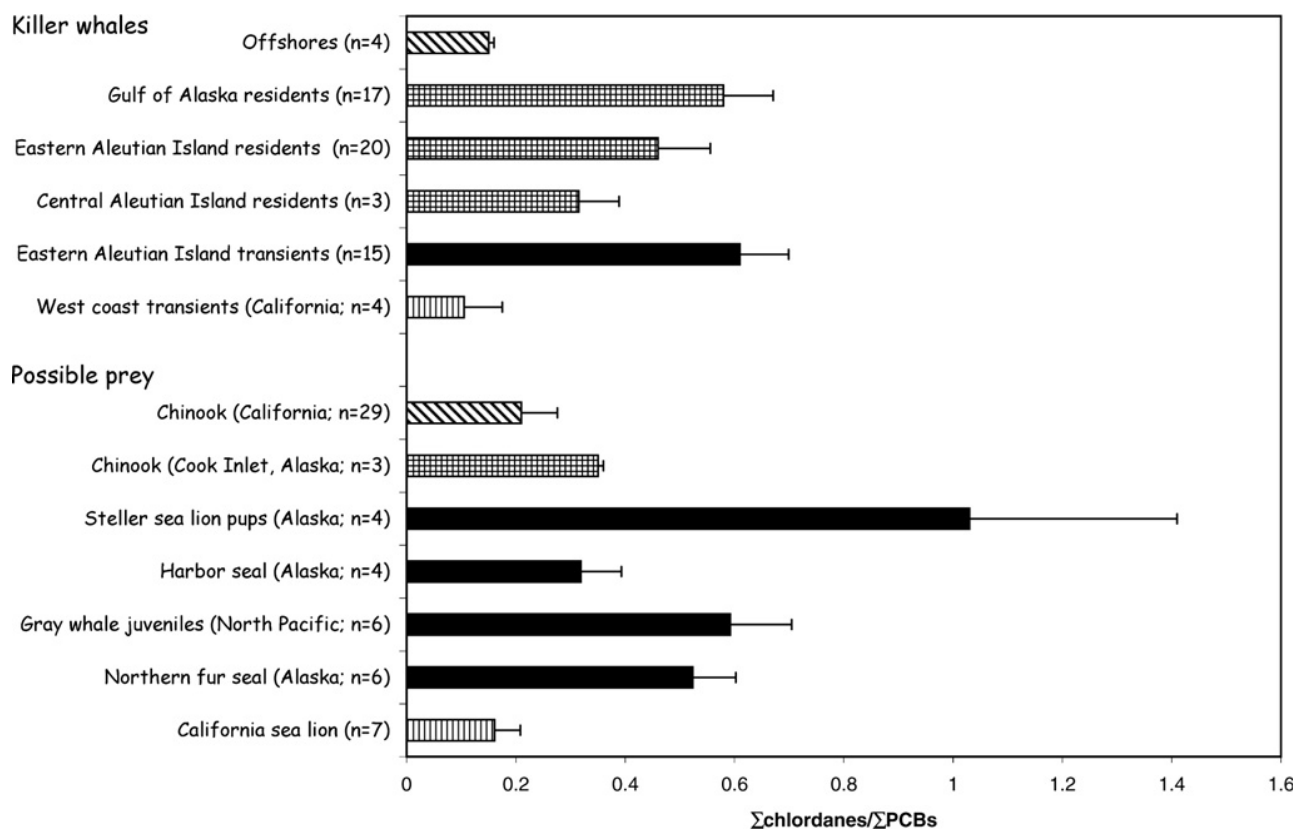

Fig. 5. The ratios $\sum$ chlordanes/ $\sum \mathrm{PCBs} \pm 1 \mathrm{SD}$ in adult male killer whale populations and selected putative prey species.

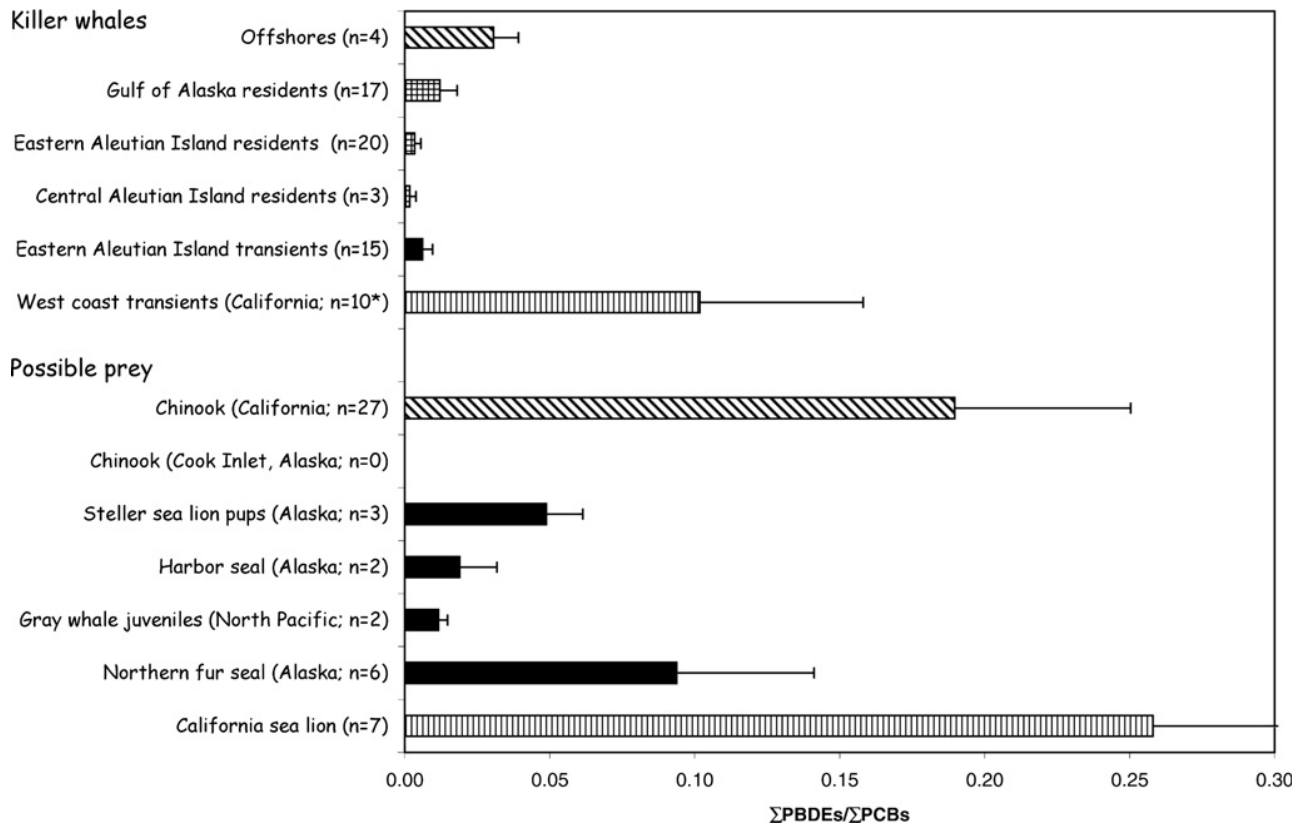

Fig. 6. The ratios $\sum$ PBDEs/ $\sum$ PCBs \pm 1 SD in adult male killer whale populations ( ${ }^{*}$ females were also used for West Coast transients) and selected putative prey species. 
Figs. 3-6. In addition ETP killer whales $(n=3)$ had a mean $\sum D D T s / \sum P C B s$ ratio of $57.8 \pm 5.2$ and a mean $p, p^{\prime}$-DDT/ $\sum$ DDT ratio of $0.061 \pm 0.005$.

When comparing POP ratios for all the killer whale groups depicted in Figs. 3-6, as well as those for ETP whales, the $\sum$ DDTs/ $\sum$ PCBs ratio was found to be significantly higher for ETP whales $(57.8 \pm 5.2)$ than for West Coast (California) transient whales and both ETP and West Coast transient whales, in turn, had $\sum D D T s / \sum P C B s$ ratios that were significantly higher than all remaining groups (Fig. 3). Mean $p, p^{\prime}$-DDT/ $/ \sum D D T$ and $\sum$ chlordanes/ $\sum$ PCBs ratios for West Coast transients were significantly lower than those found for other killer whale groups (Figs. 4 and 5). Finally, West Coast transients had significantly higher $\sum$ PBDEs/ $\sum$ PCBs ratios than found for the other whale groups (Fig. 6). When comparing POP ratios among all the Alaska killer whale groups, $\sum$ DDTs/ $\sum$ PCBs and $\sum$ PBDEs/ $\sum$ PCBs ratios were significantly higher in the offshores than in the Alaska resident or transient groups. For $p, p^{\prime}$-DDT/ $\sum \mathrm{DDT}, \mathrm{CAI} / \mathrm{R}$ had the highest and the offshores had the lowest ratios; both were significantly different from the other Alaska groups, except offshore and EAI/T whales were not different. For $\sum$ chlordanes/ $\sum$ PCBs ratios, the EAI/T and GOA/R groups were not significantly different from each other, but both were significantly higher than all other Alaska killer whale groups. When comparing the POP ratios among the three regional groups of Alaska resident killer whales, the $\sum D D T s / \sum P C B s$ ratio was highest in $\mathrm{CAI} / \mathrm{R}$ and lowest in GOA/R whales, with $\mathrm{EAI} / \mathrm{R}$ falling in between, although only the ratio for GOA/R was statistically different from those for other two groups of Alaska residents. Similarly, two other POP ratios in the Alaska resident groups showed significant west to east trends $-p, p^{\prime}$-DDT/ $\sum \mathrm{DDT}$ decreased from west to east (CAI/R higher than GOA/R), whereas $\sum$ chlordanes/ $\sum$ PCBs increased. The GOA/R group had a statistically higher ratio for $\sum$ PBDEs/ $\sum$ PCBs than found for the other two resident groups.

\section{Discussion}

The previous study (Herman et al., 2005) demonstrated that chemical profiles for resident and transient killer whales supported results from traditional methods of assessing diet (e.g., field observations and stomach content analysis), but the chemical profiles of offshore whales were seemingly contradictory. Specifically, the fatty acid profiles in the blubber of the offshore whales supported a fish diet, but POP concentrations suggested that these whales might be feeding on prey species that were more contaminated than would expected from a diet of Alaskan fish. The current study adds significant additional data from which to help resolve this apparent conflict and finds that the offshore diet is different from that of the fish-eating resident whales, particularly when contaminant ratios are added to the other chemical profiles.

Mean POP concentrations in the resident and transient killer whales (Table 3) were similar to those previously reported by Herman et al. (2005). Both in this study and the previous one, $\sum$ chlordanes and $\sum \mathrm{HCH}$ were significantly higher in the transients than in either the offshores or residents. However, in the previous study, male offshores $(n=2)$ had $\sum D D T$ and $\sum$ PCB levels that were consistently higher than those of the residents and approached, but generally did not exceed, those of the transients (Herman et al., 2005). In contrast, results for the additional offshore whales $(n=4)$, presumed to be primarily fish-eaters, had concentrations of $\sum$ DDTs and $\sum$ PBDEs that were higher than and $\sum$ PCBs that were similar to those of the Alaska transients, which, in turn, had 
concentrations of these contaminants higher than those of the residents (Table 3). Thus, the offshores are showing a very different pattern of POP contamination than found for resident and transient whales. Consequently, if the offshores consume a fish diet similar to that of the sympatric residents, the POP profile differences between the offshores and the residents are difficult to reconcile.

The ratios of certain POPs (e.g., $\sum D D T s / \sum P C B s ; p, p^{\prime}-\mathrm{DDT} / \sum \mathrm{DDT}$ ) in marine sediments and biota can be used to document unusual regional patterns of pollutants (Calambokidis and Barlow, 1991; Krahn et al., 1999; Muir et al., 1990). For example, male ETP killer whales had a mean $\sum D D T s / \sum$ PCBs ratio $(57.8 \pm 5.2)$ that was significantly higher than found for the other killer whale groups studied (Fig. 3), suggesting recent use of the DDT pesticide in the tropical Pacific that resulted in a high relative proportion of $\sum D D T s$ in prey consumed by the killer whales. This finding was supported by a relatively high $p, p^{\prime}-$ DDT/ $\sum$ DDT ratio in ETP whales $(0.061 \pm 0.005)$, indicating a recent source of the $p, p^{\prime}-$ DDT from pesticide use. Surprisingly, although the mean concentration of $\sum$ DDTs in ETP whales $(1,200,000 \pm 500,000 \mathrm{ng} / \mathrm{g}$ lipid) was about three times the mean levels found in the Alaska offshore killer whales (i.e., the group of whales biopsied in Alaska with the highest $\left.\sum D D T s\right)$, the mean concentration of $\sum$ PCBs in ETP whales $(20,000 \pm 8,300 \mathrm{ng} /$ g lipid) was only about $20 \%$ of that in the offshores. These results are consistent with both the heavy use of DDTs as a pesticide in areas of Central America (de Wit et al., 2004) and the more limited use of PCBs in a region in which industrialization has been relatively recent (de Wit et al., 2004). The highest absolute concentrations of $\sum D D T s$ and $\sum$ PCBs were found in West Coast transients sampled off California (Table 3). Both $\sum D D T$ concentrations (Table 3) and $\sum$ DDTs/ $\sum$ PCBs ratios (Fig. 3) for the West Coast transients indicated a "California signature." Furthermore, the low $p, p^{\prime}$-DDT/ $\sum$ DDTs ratio in the West Coast transient whales (Fig. 4) was also indicative of foraging in California waters, where the source of DDTs is "old", due to the US ban of DDTs in the 1970s.

For Alaska residents and transients, $\sum D D T s / \sum P C B s$ ratios (Fig. 3) were much lower than those of the West Coast transients, as would be expected because environmental availability of $\sum D D T$ s is lower in Alaska than in California (Brown et al., 1998; Calambokidis and Barlow, 1991; de Wit et al., 2004; Jarman et al., 1996). Furthermore, the primary indicator of a recent source of DDT pesticide use (i.e., $p, p^{\prime}$-DDT/ $\sum D D T s$ ) was higher in Alaska residents and transients than in the West Coast transients (Fig. 4). The input of $p, p^{\prime}$-DDT (used in Asia until recently) is consistent with the apparent transport of this pesticide to Alaska (the "Alaska signature") (AMAP, 1998; de Wit et al., 2004). The West Coast (California) transients had a significantly higher mean $\sum$ PBDEs)/ $\sum$ PCBs ratio than was found for the Alaska residents or transients, consistent with higher input of PBDEs in urban environments (de Wit, 2002). Furthermore, POP ratios for the offshore killer whales were dissimilar to those of the other Alaska groups and consistently fell between those of the West Coast (California) transients and those of the Alaska residents and transients (Figs. 3-6). In light of these differences between the offshores, residents and transients (i.e., differences in contaminant ratios; absolute $\sum$ PCB and $\sum D D T$ concentrations; POP profiles), it is apparent that offshores consume prey species having very different POPs signatures than species consumed by the resident and transient ecotypes.

Among the three regional groups of Alaska resident killer whales, POP ratios demonstrated decreasing west-to-east gradients for mean ratios of both $\sum D D T s / \sum P C B s$ and $p, p^{\prime}-\mathrm{DDT} / \sum \mathrm{DDTs}(\mathrm{CAI} / \mathrm{R}>\mathrm{EAI} / \mathrm{R}>\mathrm{GOA} / \mathrm{R})$. These results are consistent with the 
transport of DDT pesticide (particularly unmetabolized $p, p^{\prime}$-DDT) from Asia, resulting in the whales foraging closest to Asia (CAI/R residents) acquiring the highest values. In contrast, GOA/R whales had the highest mean ratios for $\sum$ chlordanes/ $\sum$ PCBs and $\sum$ PBDEs/ $\sum$ PCBs, consistent with the use of these chemicals on the mainland of Alaska (de Wit et al., 2004).

Contaminant ratios in selected representative prey species (Figs. 3-6) generally showed the same regional distinctions found for killer whales. For example, $\sum D D T s / \sum P C B s$ ratios (Fig. 3) were highest and $p, p^{\prime}$-DDT/ $\sum$ DDTs ratios (Fig. 4) were lowest (indicative of the California signature) in California prey species (Chinook salmon and California sea lions) compared to Alaska prey. In contrast, the $\sum$ chlordanes/ $\sum$ PCBs ratios (Fig. 5) were highest in Alaskan prey (particularly, Steller sea lions and northern fur seals), compared to potential prey from California. Because PBDEs are "emerging" contaminants that have not been measured until recently by many laboratories, data are only available for a relatively small number of putative killer whale prey species (Fig. 6). As would be expected for prey species that feed near large urban areas, both California sea lions and California Chinook had much higher $\sum$ PBDEs/ $\sum$ PCBs ratios than found for Steller sea lion pups from Alaska. The $\sum$ PBDEs/ $\sum$ PCBs ratio was probably lower for California Chinook salmon than for California sea lions, because the salmon spend much of their life cycle far offshore compared to the sea lions that feed regularly in coastal waters with greater urban influence. In addition, differential biomagnification of $\sum$ PBDEs and $\sum$ PCBs by these largely dissimilar taxa could cause the differences in their ratios.

Because each contaminant (or group of summed contaminants) is biomagnified to a different extent, contaminant ratios will also change as contaminants from prey are assimilated by the predator (Fisk et al., 2001; Hoekstra et al., 2003). However, biomagnification factors (BMFs) appear to be species-specific (Fisk et al., 2001; Hoekstra et al., 2003) and no BMFs have been reported for killer whales. Consequently, POP ratios cannot be directly and quantitatively compared among killer whales and their likely prey until these BMF values are known. In the interim, qualitative comparisons can be made. For example, West Coast (California) transient killer whales and California sea lions [a major transient prey species (Black, unpublished data)], had qualitatively similar contaminant signatures (specifically, high $\sum D D T s / \sum P C B s$ and $\sum$ PBDEs/ $\sum$ PCBs, as well as low $p, p^{\prime}$-DDT/ $\sum D D T s$ and $\sum$ chlordanes/ $\sum$ PCBs). Similarly, Steller sea lion pups could be a prey source for Alaska transients, because the same signature (low $\sum D D T s / \sum P C B s$ and $\sum$ PBDEs/ $\sum$ PCBs, as well as high $\sum$ chlordanes/ $\sum$ PCBs) was identified in both the transients and the sea lions. In addition, other marine mammals from the Gulf of Alaska/ Aleutian Islands area had ratios likewise indicative of an Alaska signature (e.g., northern fur seals, harbor seals; Figs. 3-6) and thus, these species should also be considered as potential prey. Alternatively, two or more marine mammal prey species may have "complimentary" ratios, where a high ratio in one species is balanced by a low ratio in others, allowing the species together to be considered as possible prey as part of a mixed diet. Contaminant ratios are only a single indicator and best used in combination with the other chemical profiles to provide a more comprehensive assessment of the most likely killer whale prey. Currently, additional prey species are being acquired and analyzed for these POPs (as well as for fatty acids and stable isotopes) and the combined results should provide additional data for comparison to the killer whales.

Taking the results from contaminant ratios, as well as the other indicators (stable isotope ratios; chemical contaminant concentrations and patterns) into consideration, 
insights into the feeding ecology of the Alaska killer whales can be further elucidated. As found in the previous study (Herman et al., 2005), all data are consistent with resident killer whales in Alaska consuming a fish diet, based on field observations and comparisons of their chemical signatures to those of other known fish-eating populations, e.g., Southern Resident killer whales (Herman et al., 2005; Krahn et al., 2004b). Interestingly, the regional groups of Alaska residents showed distinct west-to-east differences in carbon and nitrogen isotope ratios (Fig. 2). The stable isotope results were consistent with $\mathrm{CAI} / \mathrm{R}$ whales foraging in deeper, more pelagic waters, whereas GOA/R and EAI/R whales forage on prey found in shallower waters on the continental shelf (Fig. 1a). Lower $\delta^{15} \mathrm{~N}$ values at the base of the food chain in the Central Aleutian islands (Kline, 1999; Schell et al., 2000) may be a result of these oceanographic changes and thus contribute, in part, to the observed lower values in the CAI/R whales relative to the EAI/R and GOA/R groups. Furthermore, although both the EAI/R and GOA/R whales are likely consuming salmon as a substantial part of their diets (Matkin and Saulitis, unpublished data; Saulitis et al., 2000), the CAI/R residents may also be consuming locally available prey (e.g., pollock, Pacific cod, Pacific halibut), because salmon may be less available in the Central Aleutians due to lack of anadromous streams and major migratory pathways. Thus, differences in stable isotope values noted among the regional groups of resident killer whales may be significantly influenced by differences in the signatures at the base of the food chain, as well as by differences in prey specialization.

Because predation by transient (mammal-eating) killer whales may be contributing to the population declines of certain Alaskan marine mammal species, specifically Steller sea lions (National Research Council, 2003; Springer et al., 2003) and sea otters (Estes et al., 1998), there is great interest in learning more about their diet. The EAI/T whales were observed to be preying exclusively on juvenile gray whales as they transited the eastern Aleutian Islands in May, but observations later in the summer consisted of predation on northern fur seals (58\%) minke whales (28\%) and Steller sea lions (14\%) (Matkin and Saulitis, unpublished data). These observations have been substantiated through stable isotope ratios measured in the EAI/T whales. Specifically, the carbon and nitrogen stable isotope ratios for the diet of EAI/T killer whales calculated using the additive linear model were very similar to those actually measured for EAI/T transients (see Section 3). Because the $\delta^{15} \mathrm{~N}$ ratio was much higher in Steller sea lion tissues $(16.3 \pm 1.2)$ than that predicted for EAI/T prey by the stable isotope dietary model $\left(\delta_{\text {model-N }}=14.0\right)$, sea lions cannot be the exclusive prey of the EAI/T transients. Instead, their diet must be offset by the intake of substantial quantities of alternative prey species with lower $\delta^{15} \mathrm{~N}$ ratios (e.g., gray whales, Dall's porpoise, humpback whales) to be consistent with the actual $\delta^{15} \mathrm{~N}$ ratio measured for EAI/T whales. Thus, at least in spring and summer, EAI transient killer whales likely prey on a number of different marine mammal species, based on availability.

The current results for the offshores add to the complexity of determining their prey. Stable isotope ratios of offshores were statistically indistinguishable from those of EAI/ $\mathrm{R}$ residents, but were significantly lower than those of the transients (Fig. 2). Unexpectedly, contaminant ratios for offshores fell between those for the West Coast (California) transients and those for resident and transient whales from Alaska. In addition, mean $\sum$ PCB concentrations in offshores were similar to and mean $\sum D D T$ and $\sum$ PBDE concentrations exceeded those of the Alaska transients, but concentration levels were lower than those found in West Coast (California) transients (Table 3). These results are a strong indication that offshore killer whales feed during certain periods of the year in areas where 
available prey species have a "California signature." These chemical signature results were then substantiated by photoidentification, as indicated by successful matches between the 9 offshore killer whales in this study and offshores photographed in other areas. Three of the offshore killer whales biopsied in Alaska had been photographed in California, indicating that the offshores range widely from Alaska to California. Without exposure to the high levels of $\sum D D T$ s and $\sum$ PBDEs generally present in prey from the numerous highly urbanized areas along the California coast, the offshores probably could not have acquired POP concentrations and ratios indicative of a "California" signature. Furthermore, these results provide evidence that the offshore killer whales belong to a third killer whale ecotype.

The $\sum$ PCB concentrations found in the male offshores $(110,000 \pm 22,000 \mathrm{ng} / \mathrm{g}$ lipid $)$ were similar to those reported for salmon-eating "Southern Resident" male killer whales $[146,300 \pm 32,700 \mathrm{ng} / \mathrm{g}$ lipid from (Ross et al., 2000)]. Thus, it is conceivable that the offshores attained these high levels of POPs solely by consuming highly contaminated salmonids as a large portion of their diet. Alternatively, the specific preferential prey of offshore whales may be very different from those of residents and may comprise longer-lived marine fish species that bioaccumulate high levels of POPs (e.g., rockfish, shark and tuna). Therefore, rather than eating primarily the salmon species thought to be the traditional prey of their resident killer whale counterparts, offshores may alternatively consume substantial quantities of longer-lived marine fish (Black, unpublished data). To better define the prey of offshores, samples of other possible prey species (e.g., mako and thresher shark, yellowfin and albacore tuna, rockfish and squid) are currently being collected for analysis.

\section{Conclusions}

In conclusion, the chemical profiles presented here have not yet led to a complete description of the feeding ecology of eastern North Pacific killer whales, but the information provided has advanced our knowledge in several important ways. This study has three significant findings:

1. Offshore killer whales consume a diet that is clearly distinct from those of residents and transients. Furthermore, the offshores biopsied in Alaska feed at least part of the year in California, presumably on highly contaminated, long-lived, high trophic level marine fish. Thus, these results, together with those presented by Herman et al. (2005), provide further evidence that the offshores belong to a third killer whale ecotype.

2. Resident killer whales in Alaska exhibited a gradient in carbon and nitrogen stable isotope ratios, as well as in certain POP ratios, from west (central Aleutians) to east (eastern Aleutians and the Gulf of Alaska) that is likely a result of: (1) the gradient in stable isotopes at the base of the respective food webs across these regions; (2) a shift from offshelf (CAI) to continental shelf-based (GOA) prey; and (3) inclusion of lower trophic level fish prey in the diet of the $\mathrm{CAI} / \mathrm{R}$ whales relative to the other two regions.

3. The EAI/T spring/summer diet does not appear to be composed exclusively of Steller sea lions, because stable isotope ratios show that their diet must include lower trophic level species to offset the high tropic level of the sea lions. Furthermore, this conclusion is supported by field observation data indicating that gray whales, minke whales, and Northern fur seals comprise a substantial portion of the EAI/T diet during summer months. 


\section{Acknowledgements}

We greatly appreciate the technical assistance of D.W. Brown, G.M. Ylitalo, C.A. Sloan, R.H. Boyer, R.W. Pearce and J.L. Bolton in sample and data analysis. We thank G.M. Ylitalo, S. O'Neill, J. West and J. Buzitis for the Chinook salmon samples and K. Beckmen, Alaska Department of Fish and Game for Steller sea lion samples. We thank R.L. Pitman and the Southwest Fisheries Science Center for providing several biopsy samples (Z38169, Z38170, Z38171 and Z38175) and A. Schulman-Janiger for the photo-identifications of the offshore killer whales. We would also like to thank the laboratory staff of the SWFSC Population Identity Program, especially, K. Coultrup, N.M. Hedrick, A.R. Lang and K.M. Robertson for generating a portion of the genetic data used in this manuscript. We are grateful for the funding support of the North Pacific Research Board (NPRB publication \#28) and T.K. Rowles from the Marine Mammal Health and Stranding Response Program of NOAA Fisheries. In addition, funding support for field research (Matkin) was provided by the Cooperative Institute For Arctic Research, the Steller Sea Lion Recovery Initiative, the Alaska SeaLife Center and the North Pacific Universities Marine Mammal Research Consortiums. Finally, we thank L. Jones of the NWFSC Marine Mammal Program for both programmatic and financial support. Killer whale biopsy samples were collected under the following permits: NGOS NOAA Permit No. 545-1488-03; MMPA Permit Nos. 782-1510 and 782-1719, NMFS Permit Nos. 932-1489-05 and 7774-1714-03.

\section{References}

Aguilar, A., 1984. Relationship of DDE/tDDT in marine mammals to the chronology of DDT input into the ecosystem. Can. J. Fish. Aquat. Sci. 41, 840-844.

AMAP., 1998. Persistent organic pollutants. Arctic Monitoring and Assessment Programme (AMAP), Oslo, Norway.

Baird, R.W., Dill, L.M., 1995. Occurrence and behaviour of transient killer whales: seasonal and pod-specific variability, foraging behaviour, and prey handling. Can. J. Zool. 73, 1300-1311.

Barrett-Lennard, L.G., 2000. Population structure and mating patterns of killer whales as revealed by DNA analysis. Ph.D. thesis, Univ. British Columbia, Vancouver, BC.

Barrett-Lennard, L.G., Ford, J.K.B., Heise, K.A., 1996. The mixed blessing of echolocation: differences in sonar use by fish-eating and mammal-eating killer whales. Anim. Behav. 51, 553-565.

Bigg, M.A., 1982. An assessment of killer whale (Ocinus orca) stocks off Vancouver Island, British Columbia. Report of the International Whaling Commission 32, 655-666.

Black, N., unpublished data. Monterey Bay Cetacean Project.

Black, N.A., Schulman-Janiger, A., Ternullo, R.L., Guerrero-Ruiz, M., 1997. Killer whales of California and Western Mexico: A catalog of photo-identified individuals, NOAA Tech. Memo. NMFS-SWFSC-247. US Dept. Commer., San Diego, CA.

Borga, K., Fisk, A.T., Hoekstra, P.F., Muir, D.C.G., 2004. Biological and chemical factors of importance in the bioaccumulation and trophic transfer of persistent organochlorine contaminants in arctic marine food webs. Environ. Toxicol. Chem. 23, 2367-2385.

Brown, D.W., McCain, B.B., Horness, B.H., Sloan, C.A., Tilbury, K.L., Pierce, S.M., Burrows, D.G., Chan, S.-L., Landahl, J.T., Krahn, M.M., 1998. Status, correlations and temporal trends of chemical contaminants in fish and sediments from selected sites on the Pacific coast of the USA. Mar. Pollut. Bull. 37, $67-85$.

Calambokidis, J., Barlow, J., 1991. Chlorinated hydrocarbon concentrations and their use for describing population discreteness in harbor porpoises from Washington, Oregon and California. In: Reynolds, J.E., Odell, D.K. (Eds.) Marine Mammal Strandings in the United States: Proceedings of the Second Marine Mammal Stranding Workshop; 3-5 December 1987, Miami, FL, NOAA Technical report NMFS 98.

Dahlheim, M., unpublished data. NOAA/National Marine Mammal Laboratory. 
de Wit, C.A., 2002. An overview of brominated flame retardants in the environment. Chemosphere 46, 583-624. de Wit, C.A., Fisk, A., Hobbs, K., Muir, D., Gabrielsen, G., Kallenborn, R., Krahn, M.M., Norstrom, R., Skaare, J., 2004. AMAP Assessment 2002: Persistent Organic Pollutants in the Arctic. Arctic Monitoring and Assessment Program, Oslo, Norway.

Eganhouse, R.P., Pontolillo, J., Leiker, T.J., 2000. Diagenetic fate of organic contaminants on the Palos Verdes Shelf, California. Mar. Chem. 70, 289-315.

Ellis, G.M., 2005. Unpublished data, Fisheries \& Oceans Canada, Pacific Biological Station.

Estes, J.A., Tinker, M.T., Williams, T.M., Doak, D.F., 1998. Killer whale predation on sea otters linking oceanic and nearshore ecosystems. Science 282, 473-476.

Fisk, A.T., Hobson, K.A., Norstrom, R.J., 2001. Influence of chemical and biological factors on trophic transfer of persistent organic pollutants in the Northwater Polynya marine food web. Environ. Sci. Technol. 35, 732738.

Ford, J.K.B., Ellis, G.M., Barrett-Lennard, L.G., Morton, A.B., Palm, R.S., Balcomb, K.C., 1998. Dietary specialization in two sympatric populations of killer whales (Orcinus orca) in coastal British Columbia and adjacent waters. Can. J. Zool. 76, 1456-1471.

Ford, J.K.B., Ellis, G.M., Balcomb, K.C., 2000. Killer Whales: The Natural History and Genealogy of Orcinus orca in British Columbia and Washington State, second ed. UBC Press, Vancouver, BC, Canada.

Herman, D.P., Burrows, D.G., Wade, P.R., Durban, J.W., LeDuc, R.G., Matkin, C.O., Krahn, M.M., 2005. Feeding ecology of eastern North Pacific killer whales from fatty acid, stable isotope, and organochlorine analyses of blubber biopsies. Mar. Ecol. Prog. Ser. 302, 275-291.

Hoekstra, P.F., O'Hara, T.M., Fisk, A.T., Borga, K., Solomon, K.R., Muir, D.C.G., 2003. Trophic transfer of persistent orgranochlorine contaminants (OCs) within an Arctic marine food web from the southern BeaufortChukchi Seas. Environ. Pollut. 124, 509-522.

Hoelzel, A.R., Dahlheim, M., Stern, S.J., 1998. Low genetic variation among killer whales (Orcinus orca) in the eastern north Pacific and genetic differentiation between foraging specialists. J. Hered. 89, 121-128.

Hoelzel, A.R., Natoli, A., Dahlheim, M.E., Olavarria, C., Baird, R.W., Black, N.A., 2002. Low worldwide genetic diversity in the killer whale (Orcinus orca): implications for demographic history. Proc. R. Soc. Lond. B. Biol. Sci. 269, 1467-1473.

Iverson, S.J., Field, C., Bowen, W.D., Blanchard, W., 2004. Quantitative fatty acid signature analysis: a new method of estimating predator diets. Ecol. Monogr. 74, 211-235.

Jarman, W.M., Norstrom, R.J., Muir, D.C.G., Rosenberg, B., Simon, M., Baird, R.W., 1996. Levels of organochlorine compounds, including PCDDS and PCDFS, in the blubber of cetaceans from the west coast of North America. Mar. Pollut. Bull. 32, 426-436.

Jones, I., 2006. A northeast Pacific offshore killer whale (Orcinus orca) feeding on a Pacific halibut (Hippoglossus stenolepis). Mar. Mamm. Sci. 22, 198-200.

Kelly, J.F., 2000. Stable isotopes of carbon and nitrogen in the study of avian and mammalian trophic ecology. Can. J. Zool. 78, 1-27.

Kline Jr, T.C., 1999. Temporal and spatial variability of $13 \mathrm{C} / 12 \mathrm{C}$ and $15 \mathrm{~N} / 14 \mathrm{~N}$ in pelagic biota of Prince William Sound. Can. J. Fish. Aquat. Sci. 56, 94-117.

Krahn, M.M., Burrows, D.G., Stein, J.E., Becker, P.R., Schantz, M.M., Muir, D.C., O'Hara, T.M., 1999. White whales (Delphinapterus leucas) from three Alaskan stocks: concentrations and patterns of persistent organochlorine contaminants in blubber. J. Cetacean Res. Manage. 1, 239-249.

Krahn, M.M., Ylitalo, G.M., Burrows, D.G., Calambokidis, J., Moore, S.E., Gosho, M., Gearin, P., Plesha, P.D., Brownell, R.L., Blokhin, S.A., Tilbury, K.L., Rowles, T., Stein, J.E., 2001. Organochlorine contaminant concentrations and lipid profiles in eastern North Pacific gray whales (Eschrichtius robustus). J. Cetacean Res. Manage. 3, 19-29.

Krahn, M.M., Ford, M.J., Perrin, W.F., Wade, P.R., Angliss, R.P., Hanson, M.B., Taylor, B.L., Ylitalo, G.M., Dahlheim, M.E., Stein, J.E., Waples, R.S., 2004a. 2004 Status Review of Southern Resident killer whales (Orcinus orca) under the Endangered Species Act, US Dept. Commer., NOAA Tech. Memo. NMFSNWFSC-62, Seattle, WA.

Krahn, M.M., Herman, D.P., Ylitalo, G.M., Sloan, C.A., Burrows, D.G., Hobbs, R.C., Mahoney, B.A., Yanagida, G.K., Calambokidis, J., Moore, S.E., 2004b. Stratification of lipids, fatty acids and organochlorine contaminants in blubber of white whales and killer whales. J. Cetacean Res. Manage. 6, 175-189.

Krahn, M.M., Pitman, R.L., Burrows, D.G., Herman, D.P., Pearce, R.W. 2006. Assessing the feeding ecology of Antarctic Type C killer whales using chemical tracers. Paper SC/58/E13. In proceedings of IWC Scientific Committee, May/June 2006, St. Kitts, British West Indies, Unpublished data. 
Matkin, C.O. Saulitis, E.L., unpublished data. North Gulf Oceanic Society.

Muir, D., Ford, C., Stewart, R., Smith, T., Addison, R., Zinck, M., Beland, P., 1990. Organochlorine contaminants in belugas, Delphinapterus leucas, from Canadian waters. Can. Bull. Fish. Aquat. Sci. 224, 165190.

Muir, D.C.G., Ford, C.A., Rosenberg, B., Norstrom, R.J., Simon, M., Beland, P., 1996. Persistent organochlorines in beluga whales (Delphinapterus leucas) from the St. Lawrence River Estuary-I. Concentrations and patterns of specific PCBs, chlorinated pesticides and polychlorinated dibenzo- $p$-dioxins and dibenzofurans. Environ. Pollut. 93, 219-234.

National Research Council, 2003. Decline of the Steller Sea Lion in Alaskan Waters. National Academy Press, Washington, DC.

NMFS, unpublished data. National Marine Fisheries Service, Northwest Fisheries Science Center, Seattle, WA.

O’Neill, S., Ylitalo, G., Krahn, M., West, J., Bolton, J., Brown, D. 2005. Elevated levels of persistent organic pollutants in Puget Sound vs. other free-ranging populations of Pacific salmon: the importance of residency in Puget Sound. In: 2005 Puget Sound Georgia Basin Research Conference, Seattle, WA.

Ross, P.S., Ellis, G.M., Ikonomou, M.G., Barrett-Lennard, L.G., Addison, R.F., 2000. High PCB concentrations in free-ranging Pacific killer whales, Orcinus orca: Effects of age, sex and dietary preference. Mar. Pollut. Bull. 40, 504-515.

Saulitis, E.L., Matkin, C.O., Barrett-Lennard, L., Heise, K., Ellis, G.M., 2000. Foraging strategies of sympatric killer whale (Orcinus orca) populations in Prince William Sound. Alaska. Mar. Mamm. Sci. 16, 94-109.

Schell, D.M., Rowntree, V.J., Pfeiffer, C.J., 2000. Stable-isotope and electron-microscopic evidence that cyamids (Crustacea: Amphipoda) feed on whale skin. Can. J. Zool. 78, 721-727.

Sloan, C.A., Brown, D.W., Pearce, R.W., Boyer, R.H., Bolton, J.L., Burrows, D.G., Herman, D.P., Krahn, M.M., 2004. Northwest Fisheries Science Center Procedures for Extraction, Cleanup and Gas Chromatography/Mass Spectrometry Analysis of Sediments and Tissues for Organic Contaminants, F/NWC-59. NOAA Tech Memo, NMFS, US Department of Commerce, Seattle, WA.

Springer, A.M., Estes, J.A., van Vliet, G.B., Williams, T.M., Doak, D.F., Danner, E.M., Forney, K.A., Pfister, B., 2003. Sequential megafaunal collapse in the North Pacific Ocean: An ongoing legacy of industrial whaling? Proc. Natl. Acad. Sci. 100, 12223-12228.

Tollit, D.J., Steward, M., Thompson, P.M., Pierce, G.J., Santos, M.B., Hughes, S., 1997. Species and size differences in the digestion of otoliths and beaks; implications for estimates of pinniped diet composition. Can. J. Fish. Aquat. Sci. 54, 105-119.

Ylitalo, G.M., Matkin, C.O., Buzitis, J., Krahn, M.M., Jones, L.L., Rowles, T., Stein, J.E., 2001. Influence of lifehistory parameters on organochlorine concentrations in free-ranging killer whales (Orcinus orca) from Prince William Sound, AK. Sci. Total Environ. 281, 183-203.

Ylitalo, G.M., O’Neill, S., Brown, D., West, J., Bolton, J., Krahn, M. 2005a. Dietary sources of persistent organic pollutants in Southern Resident killer whales. In: 2005 Puget Sound Georgia Basin Research Conference, Seattle, WA.

Ylitalo, G.M., Stein, J.E., Hom, T., Johnson, L.L., Tilbury, K.L., Hall, A.J., Rowles, T., Greig, D., Lowenstine, L.J., Gulland, F.M.D., 2005b. The role of organochlorines in cancer-associated mortality in California sea lions (Zalophus californianus). Mar. Pollut. Bull. 50, 30-39.

Ylitalo, G.M., Yanagida, G.K., Hufnagle Jr., L., Krahn, M.M., 2005c. Determination of lipid classes and lipid content in tissues of aquatic organisms using a thin layer chromatography/flame ionization detection (TLC/ FID) microlipid method. In: Ostrander, G.K. (Ed.), Techniques in Aquatic Toxicology, vol. 2. CRC Press, Boca Raton, FL, USA, pp. 449-464.

Yonezaki, S., Kiyota, M., Baba, N., Koido, T., Takemura, A., 2003. Size distribution of the hard remains of prey in the digestive tract of northern fur seal (Callorhinus ursinus) and related biases in diet estimation by scat analysis. Mamm. Study 28, 97-102. 